\title{
port to Congress
}

\section{The Tule Elk}

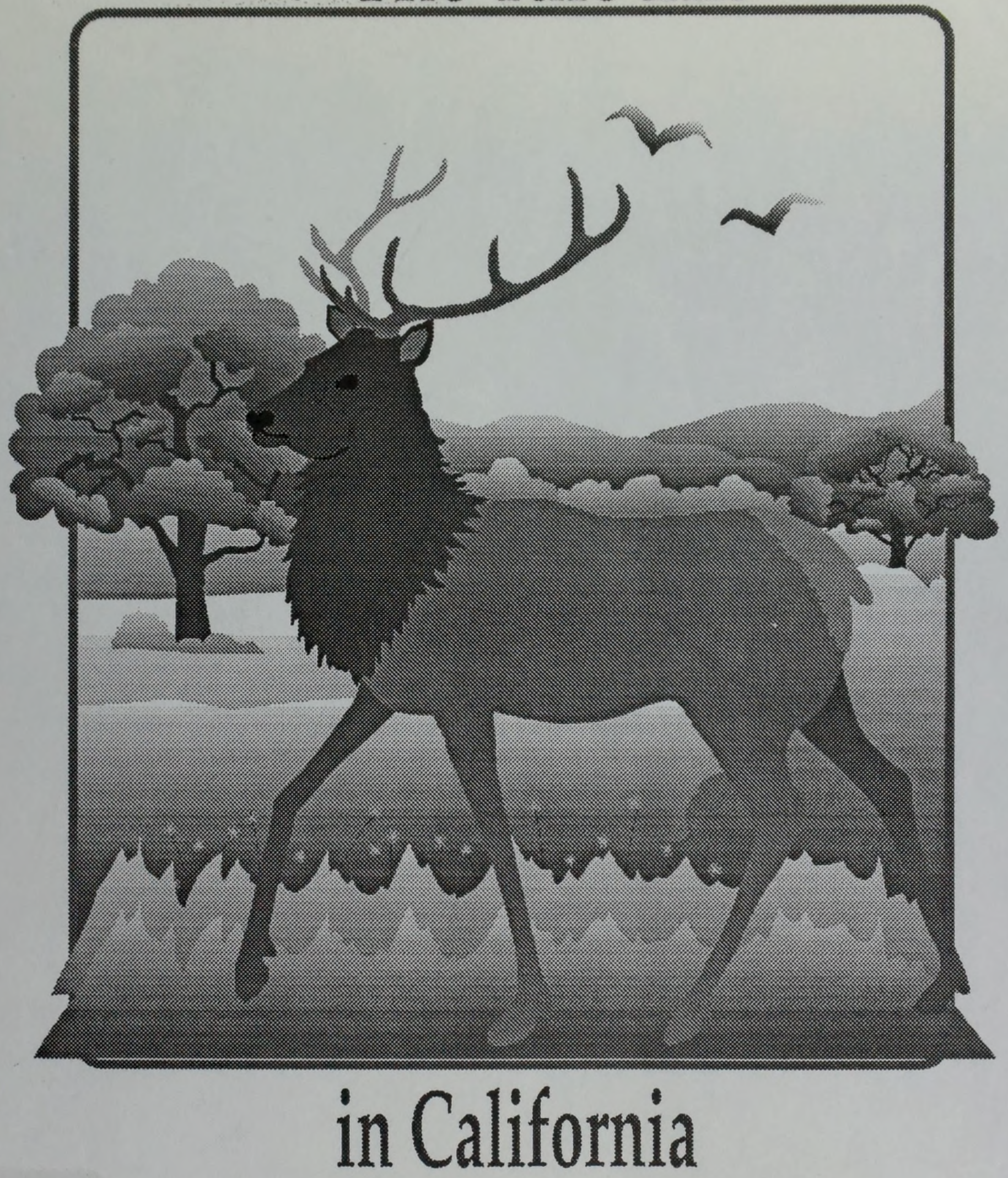

MARCH 1992

QL PREPARED BY THE 



\section{CONTENTS}

I. INTRODUCTION ....................... 1

II. HISTORY ........................... 1

III. PRESENT STATUS OF TULE ELK HERDS . . . . . . . . . . 6

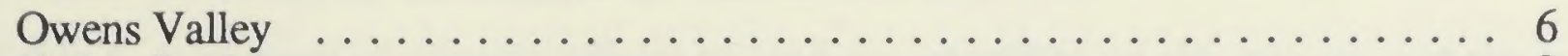

Cache Creek ......................... 9

Tule Elk State Reserve (Tupman) $\ldots . . \ldots \ldots \ldots \ldots \ldots$. . . . . . . 11

San Luis National Wildlife Refuge . . . . . . . . . . . . . . . 14

Concord Naval Weapons Station . . . . . . . . . . . . . . . . . . . . 17

Grizzly Island Wildlife Area. . . . . . . . . . . . . . . . . . 19

Mount Hamilton . . . . . . . . . . . . . . . . . . . . . 21

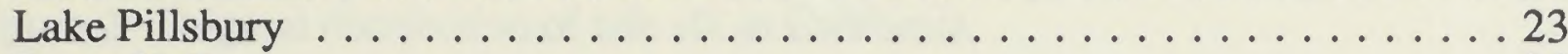

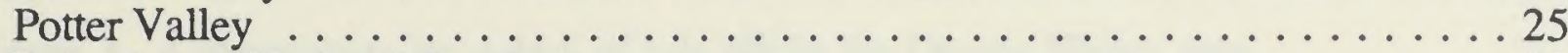

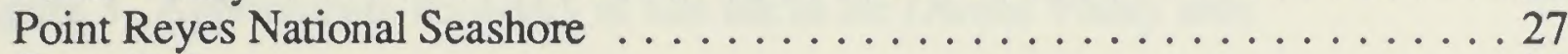

Camp Roberts . . . . . . . . . . . . . . . . . . . . . . 29

Fort Hunter Liggett $\ldots \ldots \ldots \ldots \ldots \ldots \ldots \ldots \ldots \ldots \ldots \ldots$

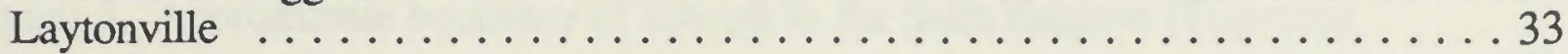

Pozo (La Panza) . . . . . . . . . . . . . . . . . . . . . . . 35

Fremont Peak ......................... 37

Potato Hill (Bartlett Springs) $\ldots \ldots \ldots \ldots \ldots \ldots \ldots \ldots \ldots \ldots \ldots$

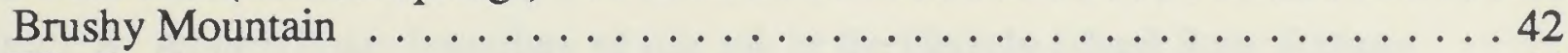

Elk Creek . . . . . . . . . . . . . . . . . . . . 44

Southern San Benito . . . . . . . . . . . . . . . . 46

Western Merced $\ldots \ldots \ldots \ldots \ldots \ldots \ldots \ldots \ldots \ldots \ldots \ldots$

Parkfield ............................. 50

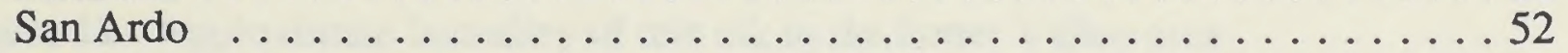

IV. RELOCATION PROPOSALS .................. 54

V. RECOMMENDED ACTIONS FOR CONTINUED MANAGEMENT

AND EXPANSION OF TULE ELK RANGE $\ldots \ldots \ldots \ldots \ldots \ldots \ldots$

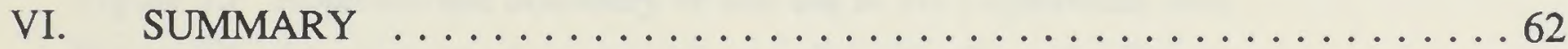

APPENDIX A: LEGISLATION AND STATE FISH AND GAME CODE . . . . . . 67

BLM Library

Denver Federal Center

Bldg. 50, OC-521

P.O. Box 25047

Denver, CO 80225 
जמo. $\mathrm{ML}$

1othe is:909\% 7mmec

ise 30 ad oble

$14025 \times 0909$ asso8 00 ievrou 


\section{TABLES}

Table 1 Status of herd units in Owens Valley

Table 2 Tule elk relocations 1989-1991

Table 3 Summary of the status of the tule elk and its habitat

Table 4 Summary of adverse effects of land-use practices on the tule elk and the status of tule elk management plans

\section{FIGURES}

Figure 1 Current distribution of tule elk herds in California

Figure 2 Original distribution of tule elk in California

Figure 3 Approximate boundary of tule elk in the Owens Valley area

Figure 4 Approximate boundary of tule elk in the Cache Creek area

Figure 5 Approximate boundary of tule elk in the State Reserve (Tupman)

Figure 6 Approximate boundary of tule elk in the San Luis National Wildlife Refuge

Figure 7 Approximate boundary of tule elk in the Concord Naval Weapons Station

Figure 8 Approximate boundary of tule elk in the Grizzly Island State Refuge

Figure 9 Approximate boundary of tule elk in the Mt. Hamilton area

Figure 10 Approximate boundary of tule elk in the Lake Pillsbury area

Figure 11 Approximate boundary of tule elk in the Potter Valley area

Figure 12 Approximate boundary of tule elk in the Point Reyes National Seashore

Figure 13 Approximate boundary of tule elk in the Camp Roberts area

Figure 14 Approximate boundary of tule elk in the Fort Hunter Liggett area

Figure 15 Approximate boundary of tule elk in the Laytonville area

Figure 16 Approximate boundary of tule elk in the Pozo (La Panza) area

Figure 17 Approximate boundary of tule elk in the Fremont Peak area

Figure 18 Approximate boundary of tule elk in the Potato Hill (Bartlett Springs) area

Figure 19 Approximate boundary of tule elk in the Brushy Mountain area

Figure 20 Approximate boundary of tule elk in the Elk Creek area

Figure 21 Approximate boundary of tule elk in the Southern San Benito area

Figure 22 Approximate boundary of tule elk in the Western Merced area

Figure 23 Approximate boundary of tule elk in the Parkfield area

Figure 24 Approximate boundary of tule elk in the San Ardo area

Figure 25 Potential tule elk reintroduction sites currently under consideration 



\section{INTRODUCTION}

This is the tenth report on the status of tule elk (Cervus elaphus nannodes) in California. The report is submitted as a requirement of Public Law 94-389, as amended by Public Law 97-375, The Joint Resolution for Federal Participation in Preserving the Tule Elk Population in California (Appendix A). This report is based on updated information provided and reviewed by the Tule Elk Interagency Task Force in November and December 1991. The contents of the report include (1) a brief history of the tule elk situation; (2) a summary of the present status and condition of individual herds and their habitats; (3) a description of relocation proposals; (4) a discussion of recommended actions for the continued management and expansion of tule elk range; and (5) a summary of the report findings and recommendations.

As of December 1991, the California Department of Fish and Game estimates there are between 2,464 and 2,747 tule elk found in 22 individual herds (Fig. 1). Information collected on age and sex composition of the State's tule elk herds indicates they continue to be healthy and expanding.

\section{HISTORY}

The tule elk, one of six subspecies of elk in North America, occurs only in California. Their original range extended from Cow Creek in Shasta County south through the Central Valley to Buena Vista Lake in Kern County, and included the San Francisco Bay area and the vicinity of Monterey, San Luis Obispo, and northern Ventura Counties (Fig. 2). Prior to the 19th Century, as many as 500,000 tule elk inhabited the central and coastal valleys of the State, with herds as large as 2,000 in the Sacramento River Delta, Tulare lake area, and Buena Vista Lake region. Today, with State and Federal protection, about 2,500 animals inhabit 22 separate areas. At least 12 of these herds are currently causing damage to private property. Most of the damage is to fences, irrigation equipment, and crops.

Significant changes to the tule elk's habitat began with the Spanish settlement of California. Introduced annuals replaced the once dominant perennial bunchgrasses, while large free-roaming herds of domestic stock started to compete with the tule elk for forage.

In the early 1800 's, a profitable hide and tallow export market was developed near the first settlements and missions of California. With no laws governing the harvest of wildlife, as many as 3,000 elk and deer hides were exported annually. The fur brigades entering the interior of California in search of beaver also took large numbers of tule elk, noticeably reducing populations in many areas.

The discovery of gold in California in 1848 changed the entire ecological, social, and economic base of the region. As the human population rapidly expanded, more land and food were needed. Unregulated market hunting of tule elk and other animals became commonplace, and, by 1860 the tule elk could be found only in the marshes of Tulare and Buena Vista Lakes. Draining of these marshes in the 1860's exposed the remaining animals to market hunting. By 1870 , tule elk were nearly extinct. 


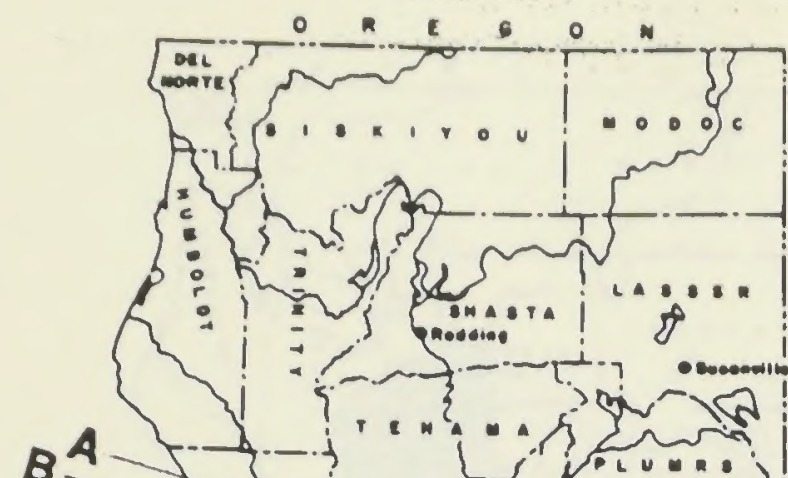

$B$

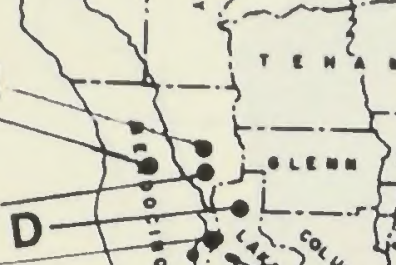

E

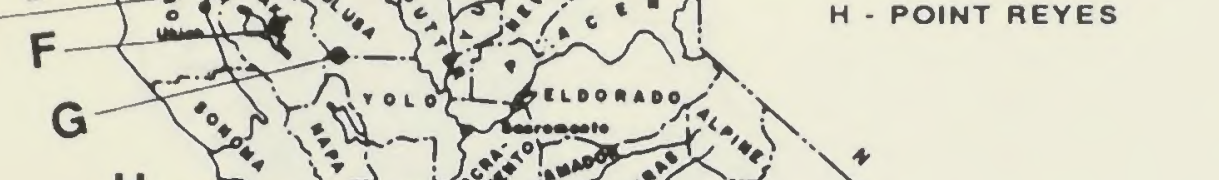

UWITEO STATES

OEPATTUENT OF THE INTERIOR

DUREAU OF LAMO MAMACEMENT

TULE ELK HERDS

1991
I- GRIZZLY ISLAND

$J$ - CONCORD

K - MT. HAMILTON

L - SAN LUIS

M - WESTERN MERCED

N - OWENS VALLEY

O - FREMONT PEAK

P - SOUTHERN SAN BENITO

o- SAN ARDO

R - HUNTER LIGGETT

S - PARKFIELD

T - CAMP ROBERTS

U - TUPMAN

V. POZO

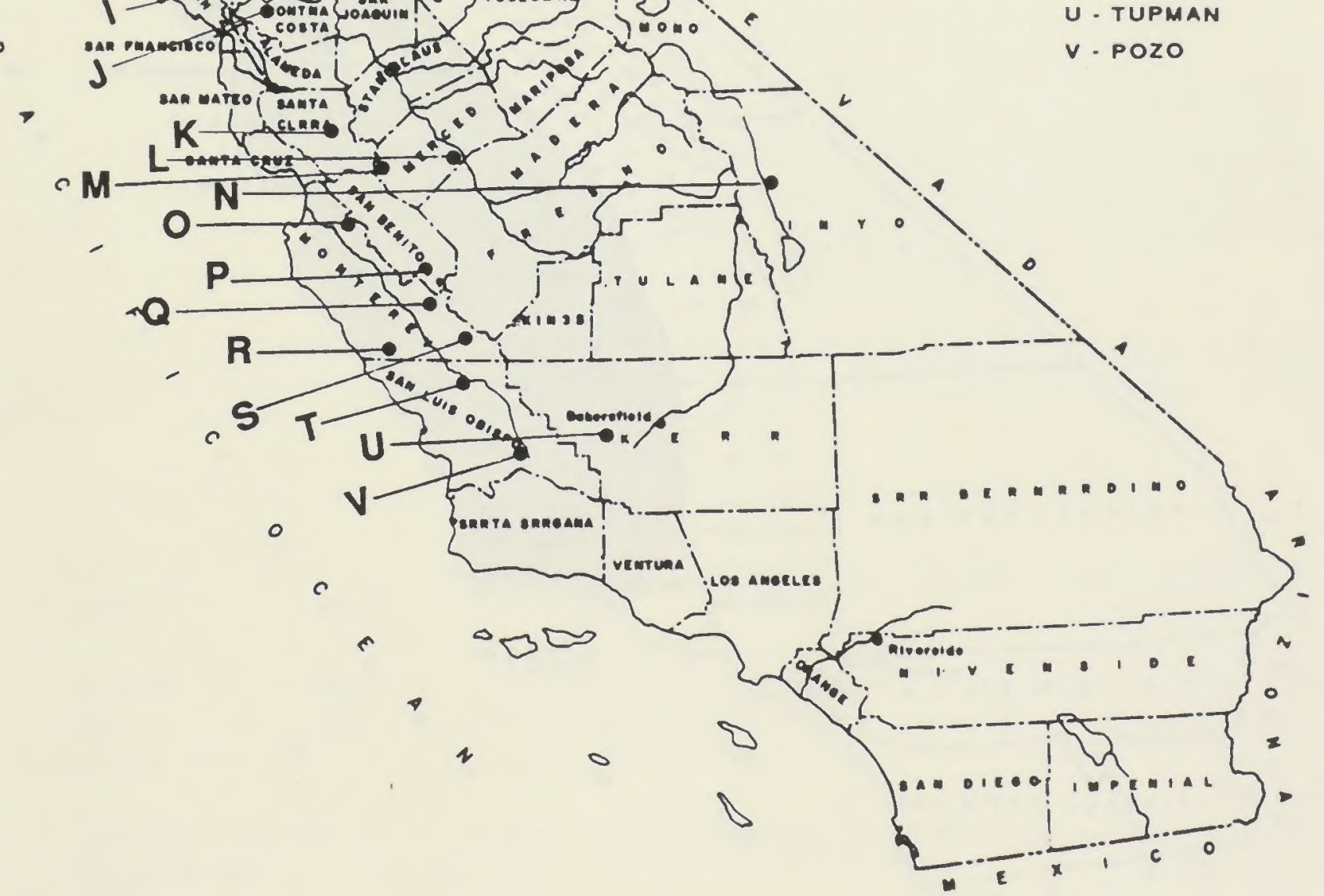

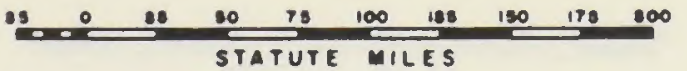





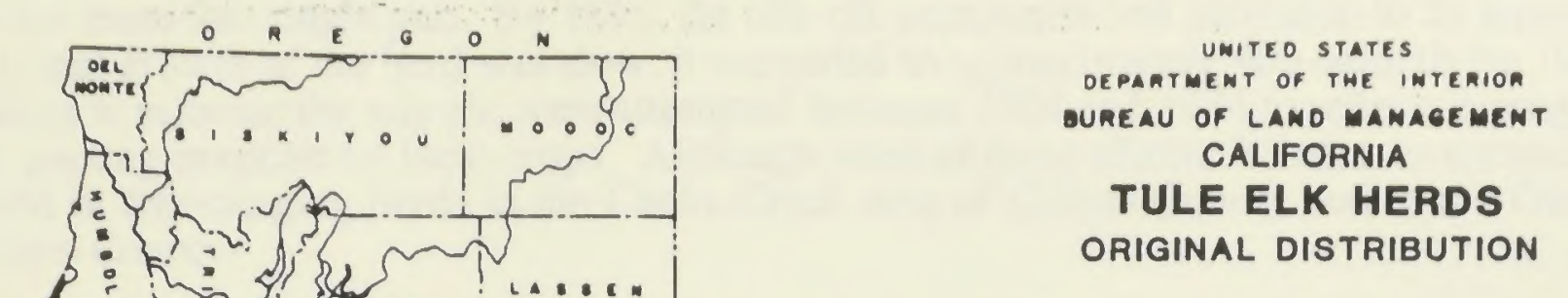

SOURCE: McCullough, D.R. 1969. The Tule Elk: its history, behavior, and ecology. Univ. Calif. Publ. Zool..

vol. 88. Berkeley and Los Angeles: Univ. of Calif. Press. 209 pp.
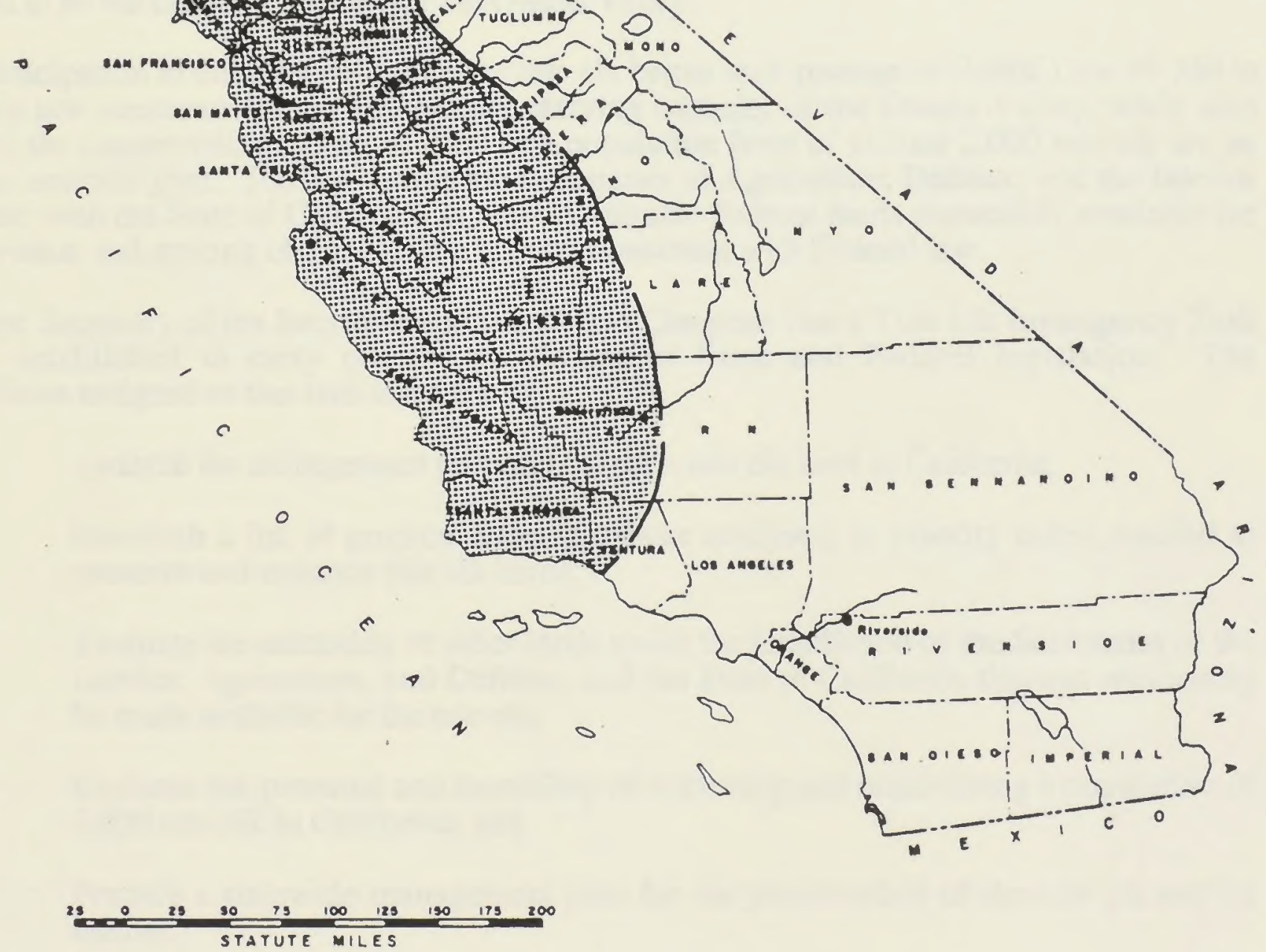

The California State Legislature responded to the plight of the tule elk and other native wildlife in 1873 when it granted elk, deer, pronghorn antelope, and bighorn sheep protection. Nevertheless, by 1875 , only a single pair of tule elk were sighted in the marsh lands of the Miller and Lux Ranch at Buttonwillow, Kern County. There is some evidence that all of the present population of tule elk descended from that single pair. By 1895, the tule elk population had increased to 28 animals. Although initial growth of the herd was slow, it expanded to approximately 400 animals by 1923. Several efforts to relocate the tule elk were attempted between 1904 and 1934 to relieve damage to fences and grazing pressure on local crops. Although most of these efforts failed, two successful ones resulted in free-ranging herds in the Cache Creek area of Colusa County and in the Owens Valley of Inyo County.

The Owens Valley herd grew rapidly and expanded its range. As the number of tule elk increased, conflicts developed between people favoring the presence of tule elk and ranchers suffering crop and fence damage. Public hunts were conducted between 1952 and 1969 to keep tule elk populations at prescribed levels and thereby reduce damage to private property. These hunts, however, were discontinued due to opposition from some members of the public.

In 1971, the California State Legislature enacted Senate bill 722. This bill prohibited the taking of tule elk until the total statewide population exceeded 2,000 animals or until the Legislature determined that suitable habitat to maintain a population of that size could not be found. This bill also limited the total number of elk inhabiting the Owens Valley to 490 or any greater number determined to be the carrying capacity of the Owens Valley.

Federal participation in the preservation of the tule elk began with passage of Public Law 94-389 in 1976. This law concurs with the 490-animal carrying capacity of the Owens Valley, while also stating that the conservation and restoration of a population level of at least 2,000 tule elk are an appropriate national goal. The law directs the Secretaries of Agriculture, Defense, and the Interior to cooperate with the State of California in making suitable Federal lands reasonably available for the preservation and grazing of tule elk in a manner consistent with Federal law.

In 1977, the Secretary of the Interior recommended to Congress that a Tule Elk Interagency Task Force be established to carry out the provisions of State and Federal legislation. The responsibilities assigned to this task force are to:

1. Analyze the management proposal for each tule elk herd in California;

2. Establish a list of projects based on those analyses, in priority order, needed to preserve and enhance tule elk herds;

3. Evaluate the suitability of other lands under the jurisdiction of the Secretaries of the Interior, Agriculture, and Defense, and the State of California that can reasonably be made available for the tule elk;

4. Evaluate the potential and feasibility of achieving and maintaining a population of 2,000 tule elk in California; and

5. Prepare a statewide management plan for the preservation of the tule elk and its habitat. 

The following Federal and State agencies are represented in the task force:

1. Bureau of Land Management (BLM) (Chairperson);

2. Forest Service (FS);

3. National Park Service (NPS);

4. U.S. Navy;

5. U.S. Army;

6. U.S. Fish and Wildlife Service (FWS);

7. California Department of Fish and Game (CDFG); and

8. California Department of Parks and Recreation (CDPR).

In addition to these government agencies, 10 other entities have participated in past task force meetings:

1. Animal Protection Institute;

2. California Wildlife Trust;

3. Committee for the Preservation of the Tule Elk;

4. Defenders of Wildlife;

5. Friends of Wildlife;

6. Fund for Animals;

7. Los Angeles Department of Water and Power;

8. Rocky Mountain Elk Foundation;

9. Sierra Club; and

10. West Coast Humane Society.

State law regarding tule elk was amended in 1987 in response to complaints about property damage. Sections 332 and 3951 of the State Fish and Game Code now state that the California Department of Fish and Game is to provide the "average of the Department's statewide tule elk population estimates" and manage tule elk herds at "biologically sound levels through the use of relocation, sport hunting or other means as determined by the Department." The Department's 1987 tule elk population estimate exceeded 2,000 animals, which was the goal of earlier State and Federal legislation. Limited hunts were approved by the Fish and Game Commission in 1988 in portions of the Owens Valley and Cache Creek herds. Litigation against the Fish and Game Commission resulted in a court order preventing the implementation of a sport hunting program during the 1988 season. In 1989, 1990, and 1991 the CDFG prepared environmental documents recommending that the Fish and Game Commission adopt regulations that provided for sport hunting of tule elk as one element of the CDFG's tule elk management program. A total of 95 tags were available in 1989, 85 tags were available in 1990, and 83 tags (plus 15-20 tags available through the private lands program) were available in 1991. 



\section{PRESENT STATUS OF TULE ELK HERDS}

The following section describes the current status of tule elk in each of the 22 areas presently occupied.

\section{OWENS VALLEY}

\section{Nature and Condition of the Habitat}

The Owens Valley is an arid, 75-mile-long valley in eastern California (Fig. 3). The habitat varies from irrigated pastures on the valley floor, to desert scrub and sagebrush on the alluvial fans, to coniferous forests in the mountains. Of the 200,000 acres within the current range of the tule elk, the city of Los Angeles and private interests own about 90,000 acres (46 percent). The BLM and USFS administer approximately 55,000 acres (27 percent) each.

Vegetation studies show that the majority of tule elk habitat in the Owens Valley is in fair to good condition. However, a few areas are in unsatisfactory condition because of overuse by livestock and wildlife. In addition, 5 consecutive years of below normal precipitation have resulted in less than optimal forage production throughout the Owens Valley, except in those areas that have continued to receive supplemental water through irrigation. Most of the irrigation occurs on the Los Angeles Department of Water and Power (LADWP) lands.

\section{Number and Condition of the Elk}

The CDFG counted 341 tule elk during an August 1991 aerial survey of the Owens Valley. Based on this survey, ground observations, and knowledge of these herds, the CDFG estimates there are currently 472-500 tule elk in the Owens Valley. Table 1 provides a comparison of annual aerial census counts conducted in 1989, 1990, and 1991.

Table 1. Annual Aerial Census Counts of Owens Valley Herd Units from 1989 to 1991.

$\begin{array}{lrrrr}\text { Herd Unit } & \underline{1989} & \underline{1990} & \underline{1991} & \begin{array}{r}\text { Recommended } \\ \text { Herd Size }\end{array} \\ \text { Bishop } & & & & \\ \text { Tinemaha } & 119 & 86 & 88 & 70-100 \\ \text { Independence } & 49 & 41 & 33 & 80-100 \\ \text { Goodale } & 65 & 66 & 70 & 60-80 \\ \text { Lone Pine } & 01 & 0 & 0 & 50-70 \\ \text { Mt. Whitney } & 136 & 127 & 108 & 60-80 \\ \text { TOTALS } & 30 & 38 & 42 & 40-60 \\ & 399 & 358 & 341 & 360-490\end{array}$

1Radiotelemetry data from the Goodale herd area indicates there is some interchange between the Goodale and Tinemaha herds. A group of 15 elk from the Goodale herd unit, for example, were observed just north of the Goodale herd boundary and were included in the Tinemaha herd count in 1988. 



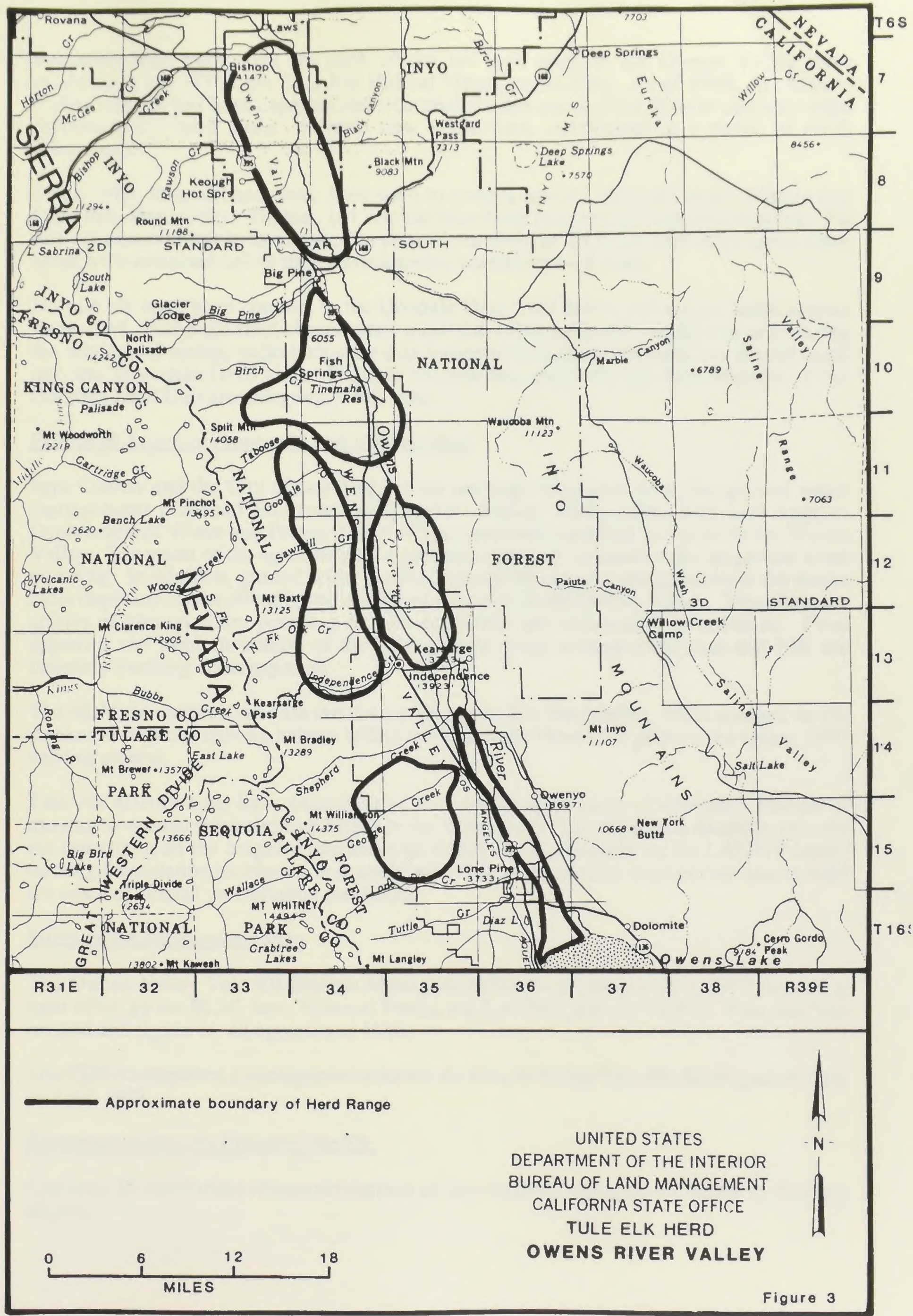



Recommended herd sizes for each of the six herd units in the Owens Valley were established in 1977 in the Tule Elk Habitat Management Plan. As of 1988, 431 Owens Valley tule elk had been captured and relocated to other parts of the State to maintain these recommended herd sizes. Several new herds were established as a result of these relocations.

Since 1989, limited hunts have been used to control tule elk numbers in the Bishop and Lone Pine Herd Units. To date, 161 tule elk have been removed by regulated hunting. No tule elk removal has been required to control numbers in the other herd units since these herds have remained below their recommended maximum herd sizes.

No tule elk have been counted in the Goodale Herd Unit during the annual aerial census since 1988. Although field observations show that a few bulls still inhabit this area during the winter and spring, radio telemetry data indicate the bulk of this herd has moved north into the Tinemaha Herd Unit. Possible reasons that most tule elk have abandoned the Goodale Herd Unit are unknown at this time.

3. Effects of Actual or Proposed Land-use Practices

Inyo County and the City of Los Angeles are nearing completion of a joint ground water management plan and Environmental Impact Report (EIR) addressing Los Angeles Department of Water and Power (LADWP) groundwater pumping activities in the Owens Valley. The intent of the agreement is to prevent impacts to vegetation due to ground water pumping. In addition, ground water studies indicate that annual precipitation is the single most important factor affecting the quality of the range in the Owens Valley. Therefore, the effects of ground water pumping on tule elk habitat are expected to be minimal. Final approval and implementation of the joint ground water management plan and EIR are currently awaiting court approval.

The BLM, in cooperation with the Rocky Mountain Elk Foundation, will construct an elk drinker to improve calving habitat within the Tinemaha Herd Unit prior to the spring 1993 calving season.

Tule elk distributions have changed due to 5 consecutive years of drought. Instead of moving to normal winter/spring ranges in the Sierra and White Mountain foothills, tule elk are remaining on the irrigated pastures and alfalfa fields available on the LADWP lands, causing depredation problems. It is anticipated this problem may become less severe with the onset of normal precipitation conditions.

4. Status of the Management Plan

The Owens Valley Tule Elk Habitat Management Plan was completed in 1977 through a joint effort by the BLM, Inyo National Forest, the LADWP, and the CDFG. This plan was revised and signed by all agencies in 1986.

The CDFG completed a management plan for the Owens Valley Tule Elk Management Unit in April 1988.

\section{Recommendations to Conserve the Elk}

Continue to implement recommendations of the existing management plans as funding allows. 



\section{CACHE CREEK}

1. Nature and Condition of the Habitat

The Cache Creek herd range totals approximately 106,000 acres of habitat in the inner coastal foothills located about 60 miles northwest of Sacramento (Fig. 4). Of this total, 68,900 acres is oak-grassland, 36,040 acres is chaparral, and 1,060 acres is riparian habitat. The BLM administers approximately one-third of this land, while the State of California administers a total of 3,700 acres through the CDFG (2,500 acres) and the State Lands Commission (1,200 acres). The remainder is private land devoted primarily to grazing.

The 5-year drought in California has resulted in poor forage conditions throughout much of the range and appears to have contributed to an overall decline in elk numbers. On some private lands, overgrazing has further negatively impacted habitat conditions. Because of the extended drought and grazing-related stress to the habitat, tule elk use during the critical summer months has primarily been in, or close to riparian areas. Cattle are not having a significant impact on BLM-administered riparian areas since there are no grazing leases here. However, on private lands such as those along Bear Creek near the intersection of Highways 16 and 20, grazing is continuing to have severe impacts.

2. Number and Condition of the Elk

The most recent population estimate available is December 1990 data from the CDFG. This estimated the Cache Creek population at between 400 and 450 animals.

Physical condition of the tule elk has been fair for several years. No unusual amounts of parasites nor any serious diseases have been found. It is known that improved forage conditions resulting from habitat improvement projects on State and Federal lands have been a benefit to the tule elk.

The Wilson Valley and Bear Creek subherds were hunted for the first time in 1989, when 15 either-sex tags were issued resulting in a harvest of seven bulls and eight cows. During the 1990 hunt, five bull tags and ten cow tags were issued, with four bulls and six cows being harvested. In 1991, six cow tags were issued, with three cows harvested.

3. Effects of Actual or Proposed Land-use Practices

Two grass seedings were completed on BLM lands in 1989. A total of 70 acres in the Wilson Valley area was seeded with perennial grasses and clovers specifically for tule elk use. The seeded area appears to be growing vigorously and provides green forage for tule elk use during a portion of the dry season.

Since 1989 there have been four prescribed burning projects for habitat improvement, totalling over 3,000 acres burned within the BLM portion of the tule elk range. Additional burns are planned on a yearly rotational basis.

Critical habitat acquisitions are being carried out. CDFG has just completed acquisition of 821 acres of oak-woodland habitat in the Harley Gulch area on the south side of Highway 20 , with an option for an additional 300 acres. The BLM is currently negotiating to purchase the Payne Ranch, which comprises over 20,000 acres adjacent to BLM lands within the tule elk range. This ranch contains critical riparian and oak-woodland habitats, and if acquired and managed primarily for wildlife values, would be extremely beneficial to this tule elk herd in the future. 



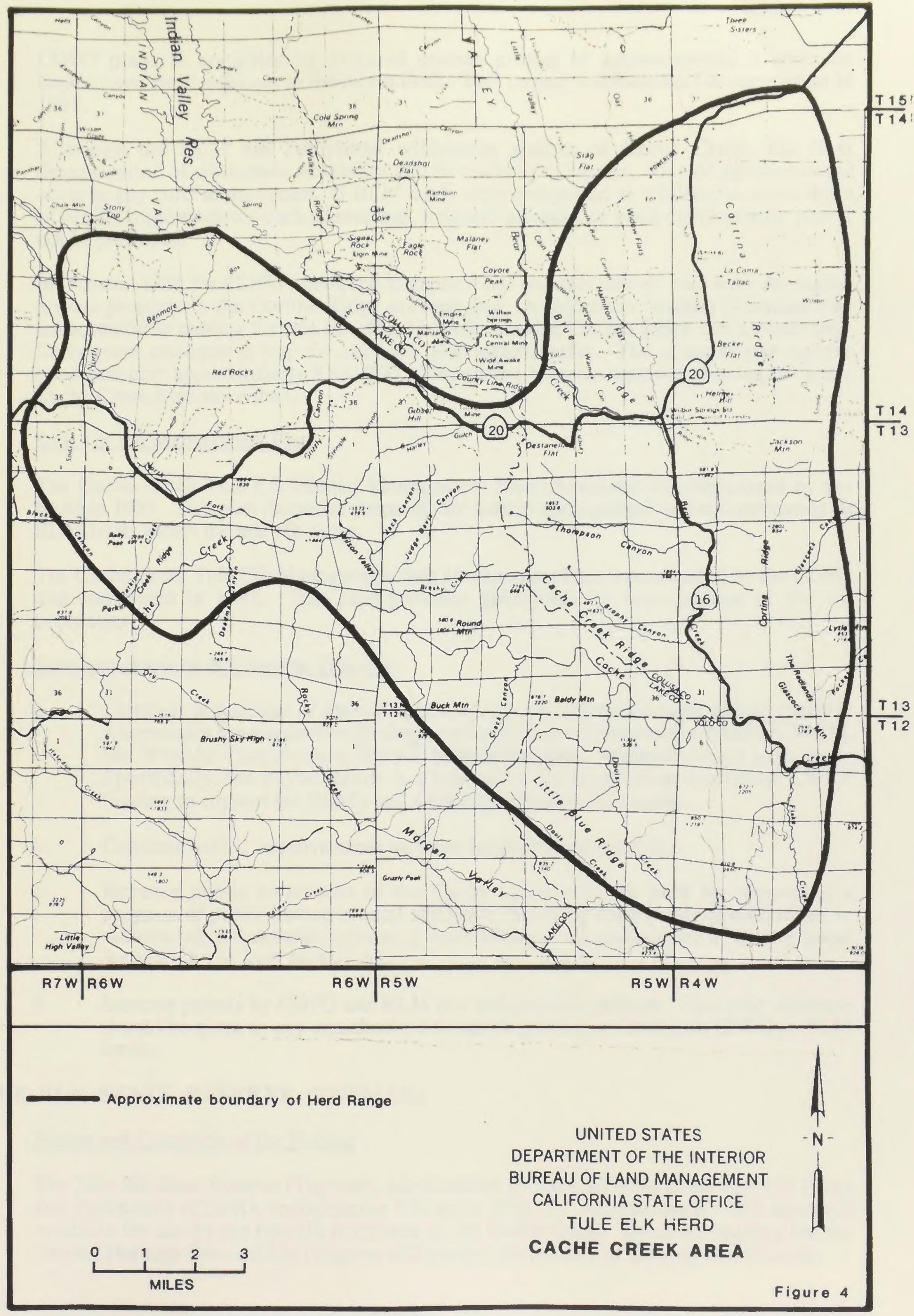



CDFG plans to complete an irrigated pasture project of approximately 5 acres on Department lands adjacent to the North Fork. This project is scheduled for completion in 1992.

Although the BLM has completed wilderness studies of Cache Creek, the final determination of wilderness suitability will be made by Congress. This designation could occur at any time in the future. If BLM lands were designated as wilderness, some types of habitat improvements such as seedings, irrigated pastures, or pond developments would not be permitted.

In October 1988 the CDFG attempted to capture and relocate tule elk that were damaging private property in the Cortina Ridge subherd area. A helicopter herding operation was unsuccessful in moving the tule elk off the heavily wooded Cortina Ridge into a corral trap. Subsequent attempts to trap the elk were also unsuccessful. The unsuccessful capture operation cost approximately $\$ 100,000$. There have been no captures or releases in the Cache Creek herd since then.

4. Status of the Management Plan

The Cache Creek Tule Elk Habitat Management Plan (Revision) was completed by the BLM in 1985. This plan discusses proposals for habitat management and enhancements on BLM lands within the tule elk range.

The Cache Creek Tule Elk Management Unit Management Plan was prepared by the CDFG and completed in 1988. This plan provides guidelines for management of the elk population.

5. Recommendations to Conserve Tule Elk

a. Continue acquisition of identified critical tule elk habitat through various funding sources and mechanisms including Land and Water Conservation Funds (LWCF), the Wildlife Conservation Board, land exchanges, or conservation easements. Specifically, the Payne Ranch is a key parcel for acquisition; continued LWCF funding to support the BLM's acquisition is critical to its success.

b. Continue habitat improvements on those lands deemed suitable.

c. Increase public awareness of the Cache Creek tule elk herd by supporting a program of public environmental education including slide shows presentations to schools and conservation groups, guided hiking tours, publication of articles about the tule elk and their habitat, etc.

d. Increase patrols by CDFG and BLM law enforcement officers. Particular attention should be given to any unauthorized livestock grazing occurring on CDFG or BLM lands.

\section{TULE ELK STATE RESERVE (TUPMAN)}

1. Nature and Condition of the Habitat

The Tule Elk State Reserve (Tupman), administered by the California Department of Parks and Recreation (CDPR), encompasses 956 acres (Fig. 5). Approximately 685 acres are available for use by the tule elk northwest of the Outlet Canal. Bond act funding for the Natural Heritage Stewardship Program will enable construction of floating fences on the 



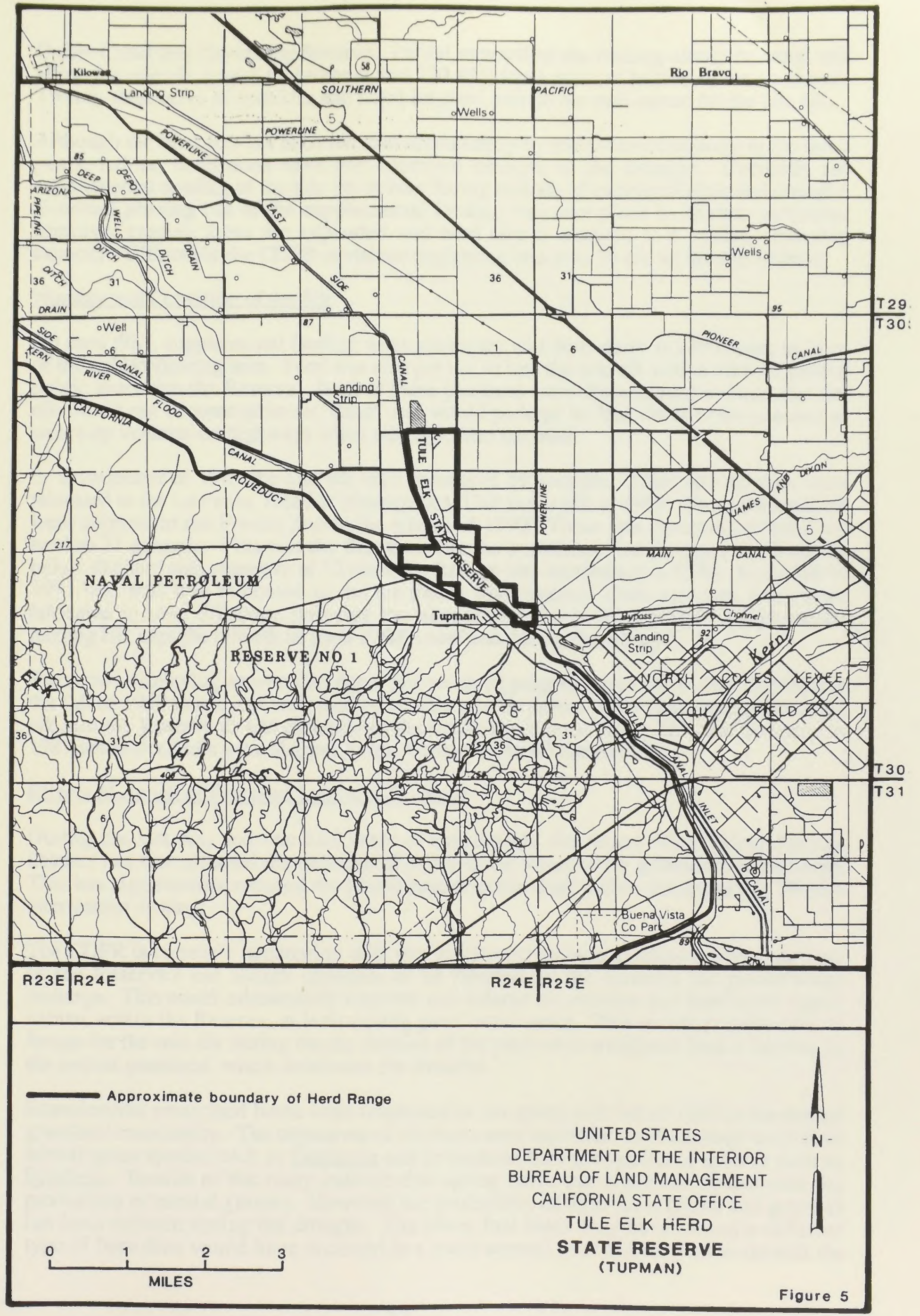



Outlet Canal that bisects the Reserve. Partial removal of the fencing along the canal will allow the tule elk access to the canal and 230 additional acres of habitat to the southwest. Twenty-three acres of sprinkler and flood irrigated pasture are maintained for the tule elk.

Although the herd size has been reduced dramatically by relocation of animals in the last 2 years, habitat conditions have not improved because of the drought. Currently the supplemental feeding of the tule elk occurs during periods of overpopulation and drought. Eventual phasing out of the supplemental feeding will take place as habitat conditions improve, grazing areas are expanded and herd size is reduced to a realistic carrying capacity. Ultimately the CDPR envisions supporting less than 30 elk within the Reserve.

2. Number and Condition of the Elk

Up until 1987, supplemental feeding when necessary was done daily at 1400 hours in front of the public viewing area. Feed was also put out to lure the tule elk within view of guided public tours into the Reserve. Both of these practices were discontinued in hope that the elk would not become quite so "tame" and would perhaps be less likely to be poached or struck by vehicles on highways when relocated into the wild.

In the summer of 1989 the tule elk herd numbered 59 animals. Thirty-six animals were relocated to the La Panza Tule Elk Management Unit in the fall of 1989. Two additional elk were shipped to the Fresno Zoo in the winter of 1990. These two removals reduced the herd to 21 animals. This was the first time that the population had dropped significantly below the herd size objective of 32 since the Refuge was established in 1934. In the fall of 1991 one bull was relocated to the La Panza Management Unit, and two bulls were relocated to Lake Pillsbury, reducing the current herd size to 22 animals. Supplemental feeding has kept the tule elk in good to fair condition during the drought.

Two cows displaying an overshot upper jaw received progesterone birth control implants in the fall of 1989 to prevent their passing on this genetic defect. CDFG has also moved tule elk into the Reserve to add diversity to the herd's small gene pool. This last occurred in 1987 when five bulls were shipped to the Reserve from the Detroit Zoo.

3. Effects of Actual or Proposed Land-use Practices

During the last two and one half years of the drought the Buena Vista Water Storage District has discontinued the delivery of water to the Reserve for groundwater recharge. This has significantly reduced the production of green feed within the Reserve's 70-acre intermittent swamp.

The CDPR is currently negotiating with two local water storage districts to allow portions of the Reserve's old slough channels to be flooded by the districts for groundwater recharge. This could substantially improve and enlarge the riparian and freshwater marsh habitat within the Reserve, at least during good water years. This would provide critical forage for the tule elk during the dry portion of the year when nutritious feed is lacking in the annual grassland, which dominates the Reserve.

Experimental prescribed burns were conducted in the spring and fall of 1990 in the annual grassland community. The objectives of the burn were two-fold: to discourage nonnative annual grass species such as Hordeum and to increase forb production of species such as Erodium. Results of the study indicate that spring burns can significantly decrease the production of annual grasses. However the production of light fuels (forbs and grasses) has been reduced during the drought. The lower fuel loads may have caused a different type of burn than would have occurred in a more normal year and may have skewed the 

results of the study. Enlarged burns will be conducted in the future to further test their effectiveness for range improvement.

In 1989 the California Department of Water Resources (CDWR) purchased 20,000 acres of land on the eastern side of the Reserve for the Kern Water Bank. Several thousand acres of the bank adjacent to the Reserve have been proposed for a joint water recharge/wetlands and uplands management area. Both CDWR and CDFG have expressed a desire to open this land to tule elk grazing.

Approximately 80 acres of private property on the western side of the Reserve have been identified for acquisition by the CDPR as an addition to the Reserve. The land contains alkali sink, intermittent slough and annual grassland habitat, and would provide an additional grazing area for the tule elk.

4. Status of Management Plan

A resource inventory of the reserve has been ongoing since 1985; endangered species work will be completed in the fall of 1991 . This information will be used to develop a Tule Elk Habitat Management Plan for the Reserve. A draft plan is scheduled for completion by the end of 1992.

5. Recommendations to Conserve the Elk

a. Continue the practice of relocating new elk into the Reserve on a regular basis to help prevent the inbreeding problems that have occurred in the past.

b. Continue relocation efforts to maintain a population below the old herd size objective of 32 animals.

c. Acquire habitat adjacent to the Reserve to increase tule elk habitat acreage.

d. Obtain the water needed to restore wetland areas within the Reserve.

e. Enter into an agreement with CDFG and CDWR to allow the tule elk to graze the Kern Water Bank land.

f. Improve the public environmental education program at the Reserve by obtaining the funding to produce and construct additional educational displays and an observation tower.

\section{SAN LUIS NATIONAL WILDLIFE REFUGE}

1. Nature and Condition of the Habitat

San Luis National Wildlife Refuge is a 7,340 acre unit of the National Wildlife Refuge System managed by the U.S. Fish and Wildlife Service (FWS). The refuge's tule elk herd is maintained within a 761 acre fenced area consisting of gently rolling perennial native grass uplands, wooded sloughs and freshwater marshes (Fig. 6). These wetlands are currently in excellent condition as a result of improved habitat management and the removal of surplus animals in 1985 . Woody browse has recovered, with willow trees producing much new growth. Upland conditions are fair to good. The continuing drought in the Central Valley has resulted in the production of thick stands of yellow star thistle which have blanketed large areas of uplands. 



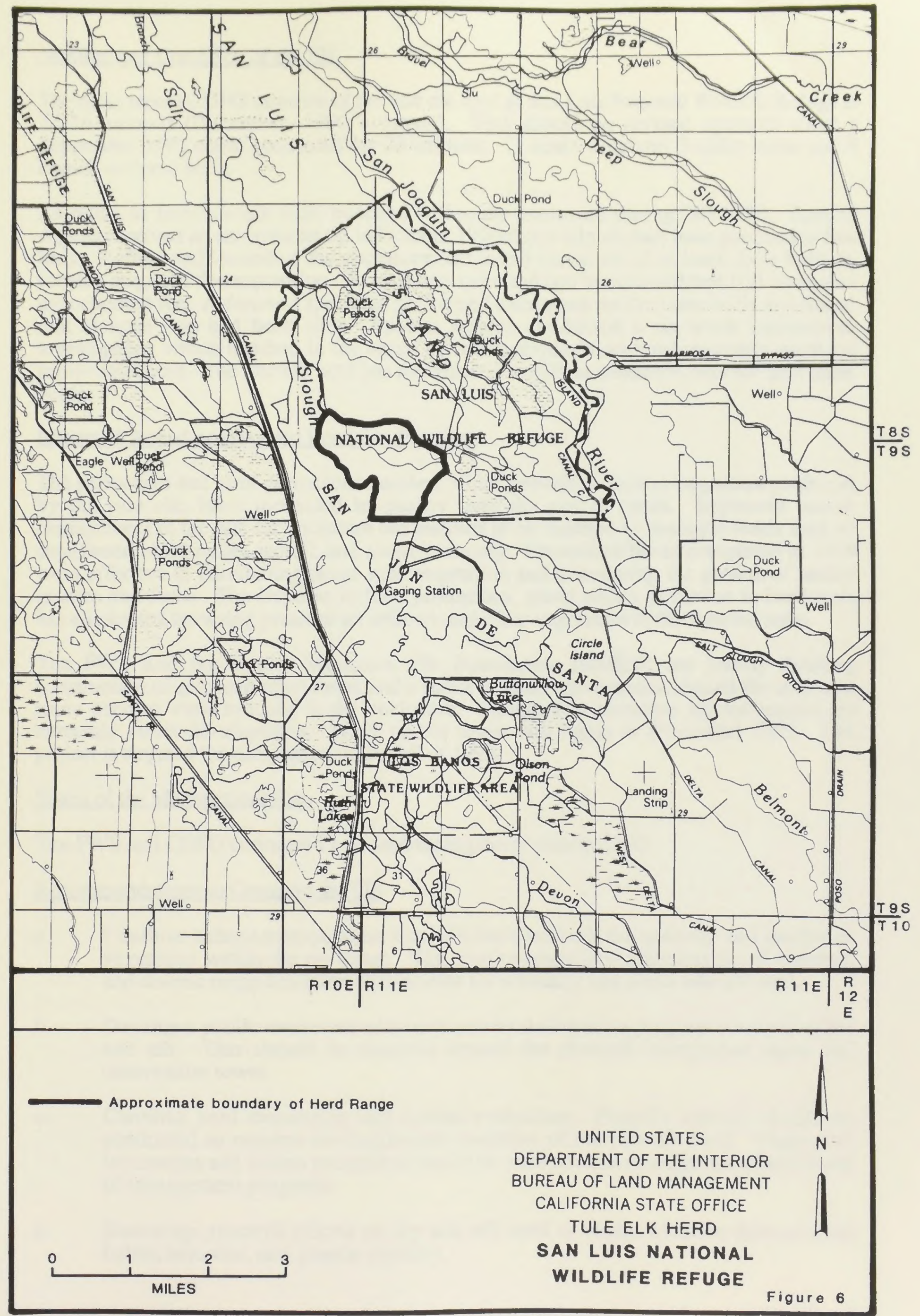



The most recent CDFG estimate of the tule elk herd at San Luis National Wildlife Refuge is 24-26 animals (December, 1990 estimate). This should be revised upwards since a September 1991 count accounted for 28 animals: 11 cows, 5 calves, 3 spike bulls, and 9 branch-antlered bulls.

As many as five tule elk were poached within the enclosure during fall 1990. Special Agents received an anonymous tip in October 1990 that a tule elk had been poached at San Luis. Refuge staff searched the enclosure and found carcasses of at least three bulls in varying stages of decomposition. At least one spike and one branch-antlered bull were also unaccounted for. A forensic specialist performed necropsies on the three bulls and found that at least two had been shot. Special Agents conducted a six-week undercover investigation which resulted in the arrest of two individuals who subsequently received prison sentences. The tule elk herd has remained in excellent condition over the past three years.

\section{Effects of Actual or Proposed Land-use Practices}

The permanent and semi-permanent marshes, which provide succulent vegetation preferred by the tule elk, have increased in quality over the past 3 years. Improved marsh management in the tule elk enclosure has resulted in an increase in desirable foods such as smartweed, wild millet, trefoil, and swamp timothy. Prescribed burns completed in 1989 were effective in eliminating dense rank vegetation and stimulating the growth of tender grasses and forbs. The increase in food production, along with a reduction in herd size, has eliminated browsing pressure on willows and other vegetation in the riparian zone.

The FWS and the Rocky Mountain Elk Foundation (RMEF) are jointly funding construction of an observation tower and a series of interpretive panels around the auto tour route used to view tule elk in the enclosure. Design and narrative for the panels are currently under development. Work on the tower will begin in December 1991. The project is targeted for completion in the fall of 1992.

\section{Status of the Management Plan}

The FWS and CDFG completed a revised management plan in 1990.

5. Recommendations to Conserve the Elk

a. Continue habitat manipulation that will increase both the quantity and quality of vegetation within the enclosure. The improvement and maintenance of vigorous and diverse range condition will provide for a healthy and stable tule elk herd.

b. Develop a public awareness and environmental education program concerning the tule elk. This should be centered around the planned interpretive signs and observation tower.

c. Continue herd monitoring and habitat evaluation. Periodic surveys should be conducted to monitor the health and condition of the tule elk herd. Vegetation inventories and habitat evaluation should be implemented to judge the effectiveness of management programs.

d. Encourage research efforts on the tule elk herd to obtain baseline data on food habits, behavior, and genetic viability. 



\section{CONCORD NAVAL WEAPONS STATION}

1. Nature and Condition of the Habitat

The Naval Weapons Station, Concord (WPNSTA Concord), located on the south edge of Suisun Bay, was offered in 1976 as a site having potential for the reintroduction of tule elk. Approximately 3,660 acres of rolling grassland with few oaks are available to the tule elk. Scattered livestock water facilities are also available for utilization by tule elk. Due to a cooperative effort by the Navy, CDFG, and the Wildlife Conservation Board, the tule elk management area (Fig. 7) is completely enclosed by a 7 -foot-high fence.

The area is annual grassland type upland habitat with only one intermittent stream and occasional springs present. Riparian habitat and green summer forage are very limited but were improved slightly by establishing a new well, stock pond, and dripline to increase succulent summer forage. These improvements are accessible to tule elk year-round. Tule elk continue to share winter and spring range with cattle; no significant negative impacts of cattle grazing on tule elk have been observed. Due to the extended drought, the current condition of the range during the fall, winter, and spring is only fair. This condition is expected to continue if the drought continues. Because this area is an annual grassland type upland habitat with only one intermittent stream and occasional springs, riparian habitat and green summer forage are very limited.

2. Number and Condition of the Elk

Although a regional drought has continued for the past 5 years, this herd continued to increase in population in 1989 and 1990. Tule elk numbers increased from 66-68 in 1988 to a peak of 83-84 animals in 1990. CDFG and the Navy captured and relocated 53 tule elk in the summer of 1990 to private property in Monterey and Merced Counties. The Concord herd was estimated by CDFG to be 28-33 animals in December 1990. The herd had increased to 37 by the fall of 1991 . The tule elk have grown accustomed to vehicle traffic but are still quite wild and wary of pedestrians.

3. Effects of Actual or Proposed Land-use Practices

The Navy leases approximately 80 percent of the tule elk area for seasonal cattle grazing. Range management plans restrict the grazing season (1 November through 31 May in most years) as well as the number of animal unit months allowed in each area. Cattle periodically displace tule elk from specific grazing sites, but do not appear to adversely affect tule elk since their numbers have increased under the seasonal cattle grazing program. Cattle are removed during the dry summer season.

There have been several reductions in the areas potentially available for tule elk use due to Navy construction and plans to build a regional rapid transit corridor through a portion of the tule elk range. As this construction occurs in areas rarely used by tule elk, it is unlikely the species will be adversely affected by these activities.

The Contra Costa irrigation canal continues to be a source of death due to drowning or secondary infections of animals which escape the canal. Replacing gates with cattle guards to keep tule elk out of the canal has not been effective. 



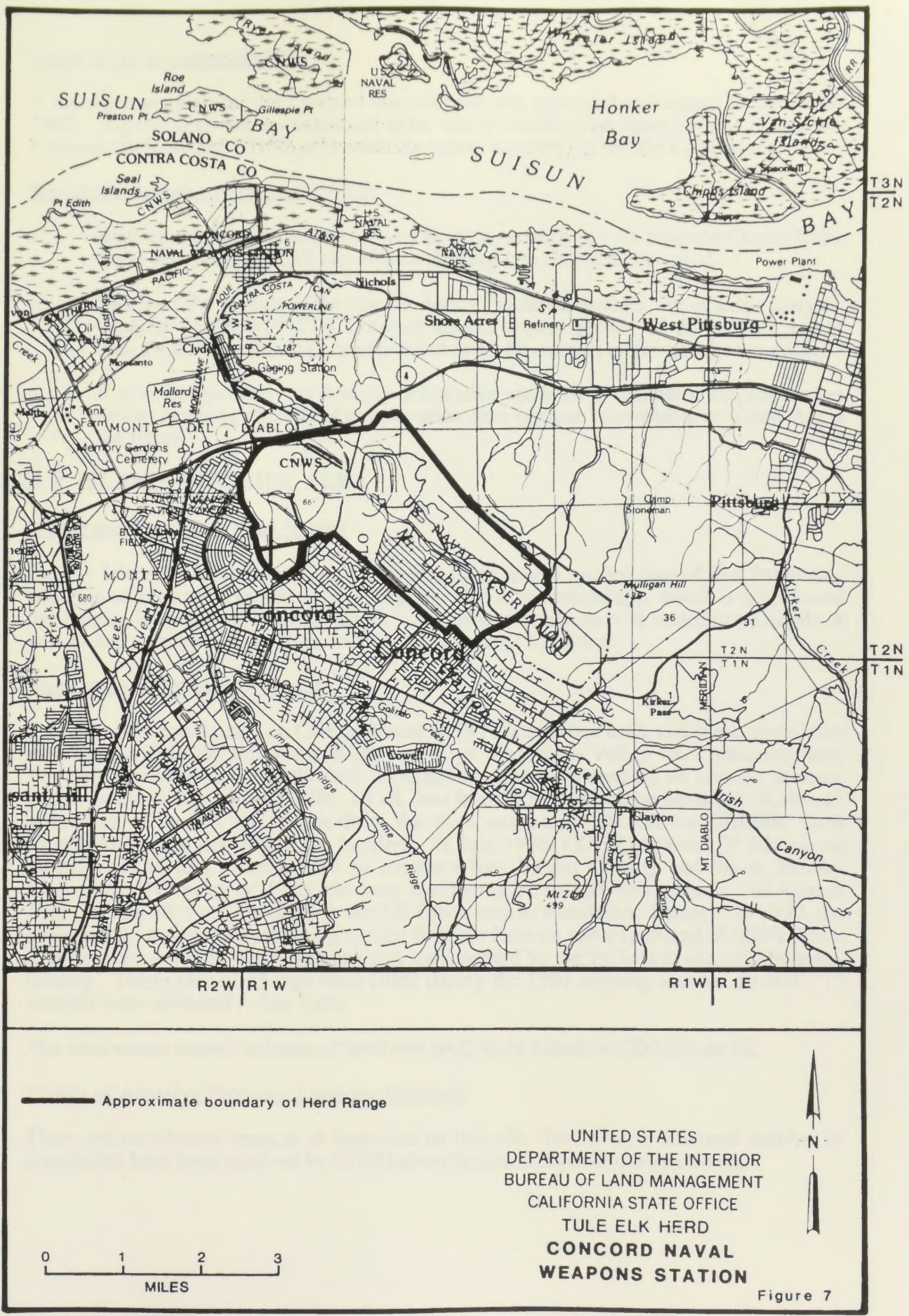





\section{Status of the Management Plan}

A management plan for the Concord tule elk herd was approved and signed in December 1982. Signed with the management plan was a cooperative management agreement between the Navy and CDFG to provide the means for carrying out the management plan.

\section{Recommendations to Conserve the Elk}

a. Replace the four-strand barbed-wire fence separating tule elk from the Contra Costa canal with a fence which can effectively keep tule elk out of the canal.

b. Based on the success of the tule elk during the recent drought, increase the carrying capacity of the WPNSTA Concord herd to approximately 80-85 animals, rather than the current carrying capacity listed as 45-50 animals in the management plan.

c. It may be necessary to develop alternative methods to maintain the population within carrying capacity if translocation sites become unavailable or unfeasible in the future.

\section{GRIZZLY ISLAND WILDLIFE AREA}

\section{Nature and Condition of the Habitat}

Grizzly Island Wildlife Area is an 8,600 acre State refuge located east of San Pablo Bay which is administered by the CDFG (Fig. 8). The unfenced refuge, which is surrounded by sloughs, is composed of barley fields and natural marshlands with intermittent stands of willow and eucalyptus trees. The habitat is in excellent condition.

\section{Number and Condition of the Elk}

Tule elk were established on Grizzly Island in 1977 when four bulls and three cows from the Tupman Tule Elk Reserve and one cow from the Owens Valley were relocated here. The herd has expanded rapidly with population increases exceeding 36 percent in some years. In the winter of 1985-1986, 16 elk died from ingesting poison hemlock. Although a number of factors are responsible, the high number of elk on the Wildlife Area contributed to the severity of the incident. In July 1986, CDFG captured 77 tule elk on Grizzly Island and relocated 57 to southern San Benito County and 20 to Brushy Mountain. By spring of 1988, the herd had increased to 135-140 animals. In August 1988, 40 tule elk were relocated to the Elk Creek area in Mendocino County. In 1990, ten bulls and 20 cows were taken during the first elk hunt on Grizzly Island Wildlife Area. Eleven more animals were captured and translocated to the Parkfield area of Monterey County. Thirty-two of 33 tags were filled during the 1991 hunting season. In 1991, 13 animals were relocated to San Ardo.

The most recent overall estimate of herd size on Grizzly Island is 100-105 tule elk.

\section{Effects of Actual or Proposed Land-use Practices}

There are no adverse impacts of land uses on tule elk. However, a minimal number of complaints have been received by CDFG about farmland depredation by tule elk. 



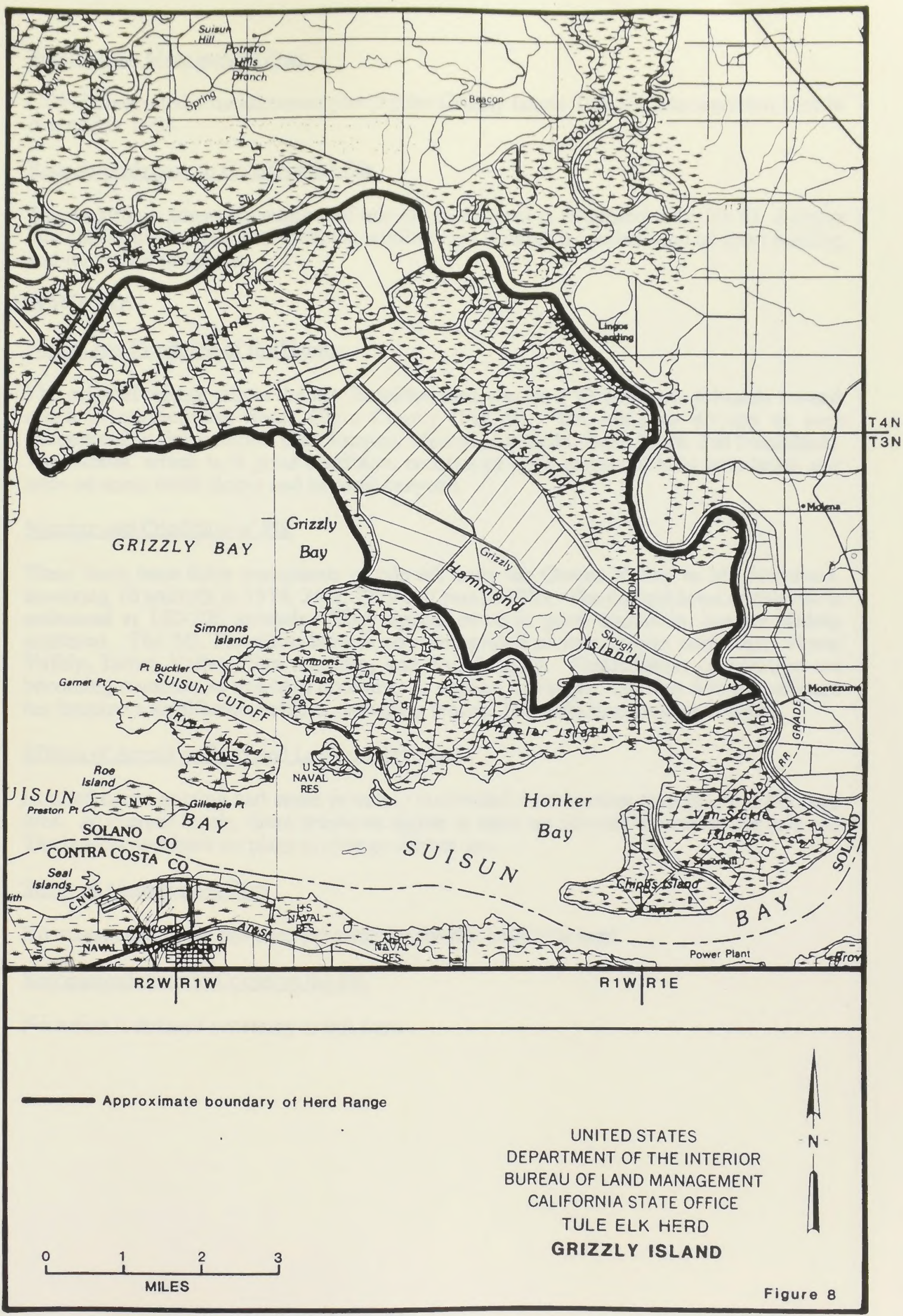



4. Status of the Management Plan

CDFG completed a management plan for the Grizzly Island Tule Elk Management Unit in November 1988.

5. Recommendations to Conserve the Elk

The maximum allowable number of tule elk in this area is estimated to be 50-70. Surplus tule elk should be removed from the wildlife area through a combination of sport hunting and relocation programs.

\section{MT. HAMILTON}

1. Nature and Condition of the Habitat

The original release site in the Mt. Hamilton area was on a 35,000 acre, privately owned ranch in northeastern Santa Clara County (Fig. 9). The elk now occupy an area encompassing five counties (San Joaquin, Merced, Alameda, Santa Clara, and Stanislaus). The habitat, which is in good condition, consists of open grassland hills with brush and trees on some north slopes and in some canyons.

2. Number and Condition of Elk

There have been three transplants of tule elk from the Owens Valley to Mt. Hamilton, involving 16 animals in 1978, 21 in 1979 and two in 1980. The current level of tule elk is estimated at 180-205 animals. They appear to be in good condition, but are widely scattered. The Mt. Hamilton herd is now comprised of four known subherds; Horse Valley, Isabel Valley, San Antonio, and San Joaquin. Depredation complaints are becoming common as this herd continues to expand its range. The San Joaquin subherd has become a significant problem, damaging fences. Reproductive success is good.

3. Effects of Actual or Proposed Land-use Practices

Limited cattle grazing and some privately controlled deer hunting take place in the herd area. At current levels, these practices appear to have no adverse effects on the tule elk. The landowners have no plans to change current use.

4. Status of Management Plan

No management plan has been prepared for the Mt. Hamilton herd.

5. Recommendations to Conserve the Elk

No action is deemed necessary at this time. 



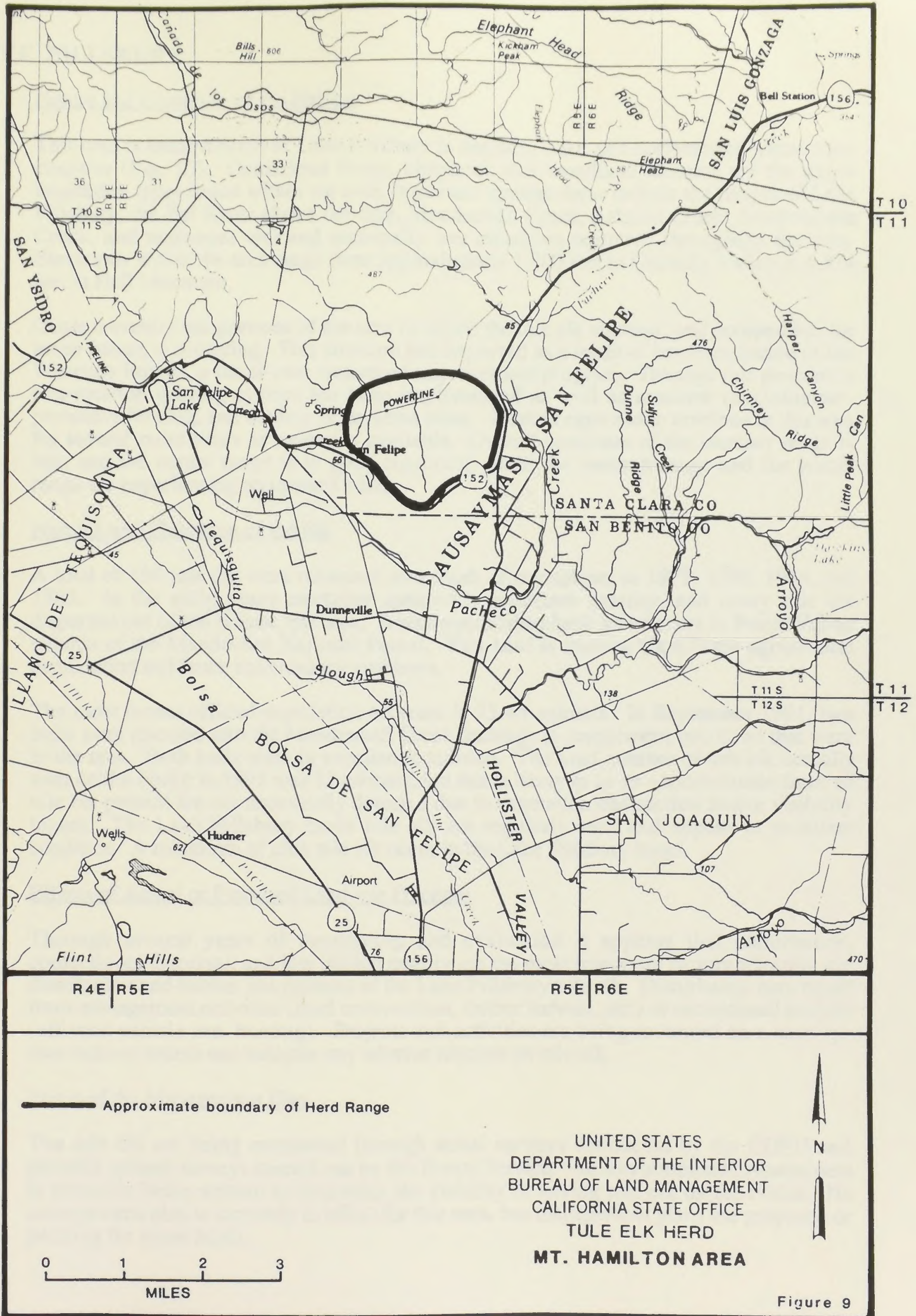





\section{LAKE PILLSBURY}

1. Nature and Condition of the Habitat

This area is located north of Lake Pillsbury in northern Lake and northeastern Mendocino counties (Fig. 10). Coniferous forest, chaparral, and woodland savanna are the major vegetation types found within the area. Important riparian areas include the fringes of Lake Pillsbury, the Eel River above the lake, Mendenhall Creek, Salmon Creek, Smokehouse Creek, and numerous wet and seasonally wet meadows scattered throughout the area. Elevations within the area range from approximately 1,800 feet in Gravelly Valley to 6,874 feet at Hull Mountain.

Cattle currently use portions of the area in which the tule elk summer, and competition for green forage is occurring. This situation has improved as a result of implementation of the Westside Project, a multi-year watershed improvement program. Through this program a rest-rotation grazing system has been implemented as well as meadow rehabilitation, protective fencing, and seeding of depleted areas. Work is expected to continue in this area for several more years as money is available. Overall condition of the summer range is fair, and the winter range is in good condition. Both the summer range and the winter range are experiencing an upward trend.

\section{Number and Condition of the Elk}

A total of 156 tule elk were relocated as a result of transplants in 1978, 1980,1984, and 1985. In the early years mortality apparently exceeded natality, and many tule elk dispersed out of the release site area. A well-established herd now occurs in Potter Valley outside of the Mendocino National Forest. This herd is causing significant agricultural depredation and fence maintenance problems.

The most recent official population estimate is 25-45 animals. In September 1991, two bulls were released into the Mendenhall Creek drainage to supplement two cows that were in the area. Both bulls were in excellent condition. The total number of tule elk actually seen on the Forest in 1991 was 12 animals, but this is likely to be an underestimate since all tule elk present are not necessarily detected due to vegetation obstruction and/or visibility biases. The Lake Pillsbury basin tule elk are regularly seen and appear in excellent condition. A minimum of nine tule elk occur in the Lake Pillsbury basin.

3. Effects of Actual or Proposed Land-use Practices

Through several years of monitoring and evaluation it appears that disturbance, competition, dispersal, and low habitat quality are the most important factors affecting the distribution and habitat use patterns of the Lake Pillsbury tule elk. Disturbance may result from management activities (road construction, timber harvest, etc.) or recreational activity (off-road vehicle use, hunting). Projects and activities are being reviewed on a case-bycase basis to assess and mitigate any adverse impacts on tule elk.

\section{Status of the Management Plan}

The tule elk are being monitored through aerial surveys conducted by the CDFG and periodic ground surveys carried out by the Forest Service. An Environmental Assessment is presently being written to determine the viability of having tule elk on the Forest. No management plan is currently in effect for this area, but management plans are proposed or pending for some herds. 



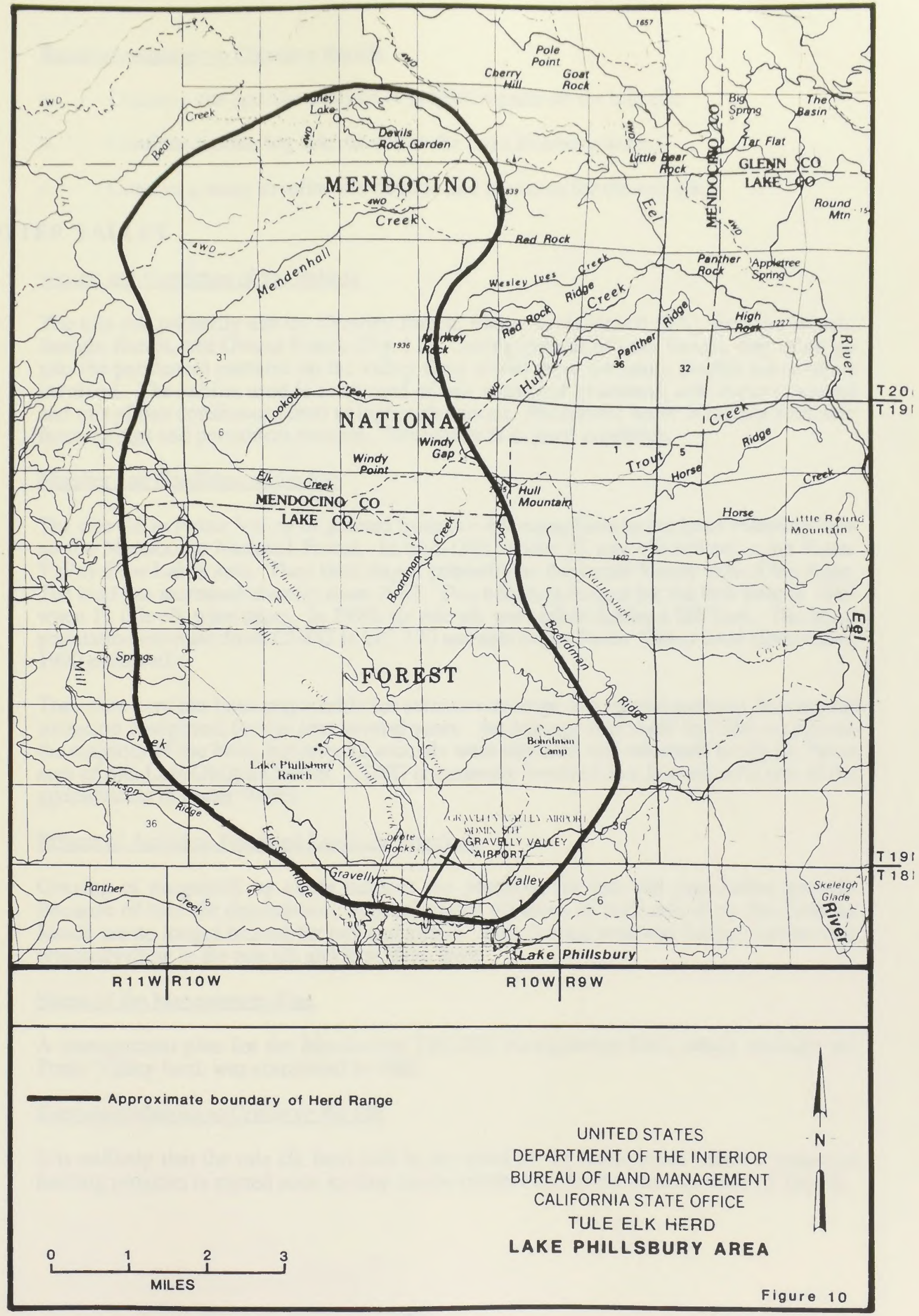



5. Recommendations to Conserve the Elk

a. Continue site-specific analysis of project impacts on the tule elk.

b. Continue monitoring tule elk within the Lake Pillsbury basin.

c. Conduct a study to refine distribution and use areas for the tule elk.

\section{POTTER VALLEY}

1. Nature and Condition of the Habitat

The tule elk primarily use the Guntley Ranch, Shore Acres Ranch (SA), Fritsche Ranch, Enright Ranch, and Owens Ranch (Fig. 11). During periods of poor forage, they often go into the permanent pastures on the valley floor where there are many smaller ownerships involved. The habitat used is composed of oak woodland-grassland with some chaparral and mixed oak coniferous forest at higher elevations. Permanent water is readily available from springs and permanent streams. The habitat is in good condition.

\section{Number and Condition of the Elk}

The tule elk in Potter Valley originated from two elk transplants to the Lake Pillsbury area on the Mendocino National Forest. In mid-1981, about 15 tule elk settled in the Potter Valley-Blue Lakes area. They later stayed primarily on the Potter Valley side of the ridge. The herd has increased steadily since 1982. This herd was hunted for the first time in 1989 when 11 tule elk were taken. In 1990, six tule elk were taken during a fall hunt. The latest population estimate from CDFG is 125-130 animals in the Potter Valley herd (December, 1990 estimate).

The entire herd has been responsible for extensive damage to irrigated pastures, fences, and irrigation equipment for the past several years. An attempt was made in 1986 to relocate the majority of the herd, but only 12 animals were captured and relocated to the La Panza area of San Luis Obispo County. CDFG is currently involved in a lawsuit with one of the agriculturists in Potter Valley.

3. Effects of Actual or Proposed Land-use Practices

Grazing of rangeland by cattle reduces the potential for tule elk population growth. Because of tule elk depredation, approximately 60 acres of bottomland on the Fritsche Ranch are no longer farmed for hay and alfalfa. This farmed area was the key habitat that originally drew in the tule elk and kept them there.

4. Status of the Management Plan

A management plan for the Mendocino Tule Elk Management Unit, which includes the Potter Valley herd, was completed in 1988.

5. Recommendations to Conserve the Elk

It is unlikely that the tule elk herd will be accepted by the landowners unless a managed hunting program is started soon so they can be reimbursed for the damage done by the elk. 



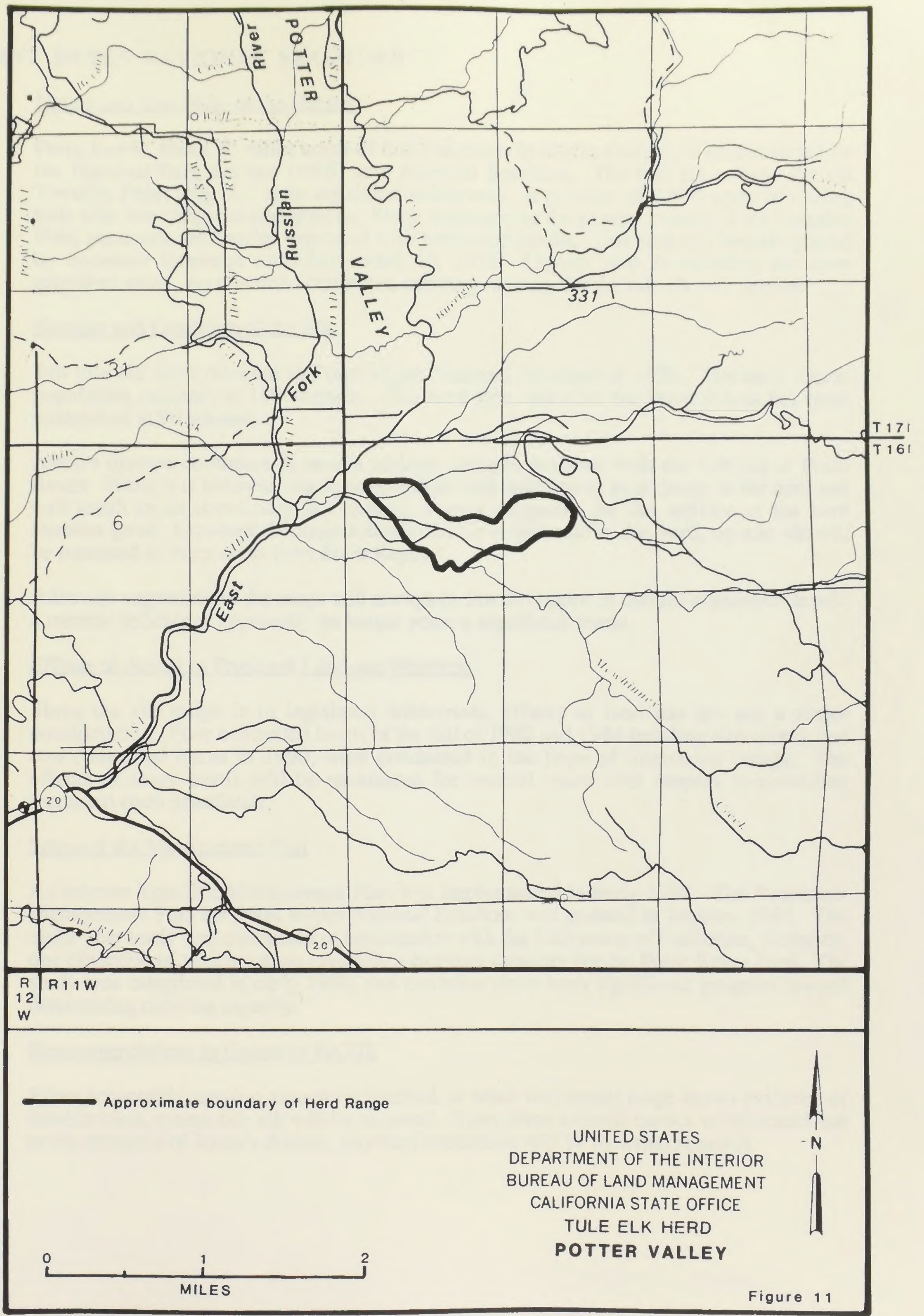





\section{POINT REYES NATIONAL SEASHORE}

\section{Nature and Condition of the Habitat}

Point Reyes, about 40 miles north of San Francisco in Marin County, is administered by the National Park Service (NPS) as a National Seashore. The tule elk release site on Tomales Point (Fig. 12) is in legislated wilderness. It consists of 2,600 acres of rolling hills with low chaparral and grasses. Steep drainages on the eastern portion of the Tomales Point peninsula are heavily vegetated with hardwood shrubs. This area was heavily grazed by domestic livestock until November 30,1979. Coyote bush is invading the open grassland areas. As this trend continues, carrying capacity for the tule elk will decline.

\section{Number and Condition of the Elk}

Ten tule elk were released in Point Reyes National Seashore in 1978. The most recent population estimate is 180 animals. The herd size objective for Point Reyes has been established at 90 animals.

Johne's disease continues to pose a serious, chronic problem with the tule elk at Point Reyes. While it is believed that Johne's disease will continue to be endemic in the herd and will result in an occasional lost animal, overall prognosis for the welfare of the herd remains good. However, because Johne's disease is endemic in this herd, no tule elk will be relocated to other areas from Point Reyes.

Although vegetation in the range will always be low in copper, at current population levels, a mineral deficiency apparently no longer poses a significant threat.

\section{Effects of Actual or Proposed Land-use Practices}

Since the elk range is in legislated wilderness, effects of land use are not a major consideration. Four controlled burns in the fall of 1982 and 1984 (totaling 476 acres), and two controlled burns in 1990, were conducted in the hope of improving forage. The effects of these burns will be monitored for several years with respect to providing increased open grasslands.

\section{Status of the Management Plan}

An interim Tule Elk Management Plan was implemented in early 1982. The Resources Management Plan for Point Reyes National Seashore was updated in January, 1987. The multi-year study was conducted in conjunction with the University of California, Berkeley, one objective of which was to establish a carrying capacity for the Point Reyes herd. The study was completed in early 1986, and there has since been significant progress toward determining carrying capacity.

\section{Recommendations to Conserve the Elk}

When acceptable carrying capacity is reached, or when the current range shows evidence of deterioration, excess tule elk will be removed. Since these animals cannot be relocated due to the presence of Johne's disease, any herd reductions will be by lethal removal. 



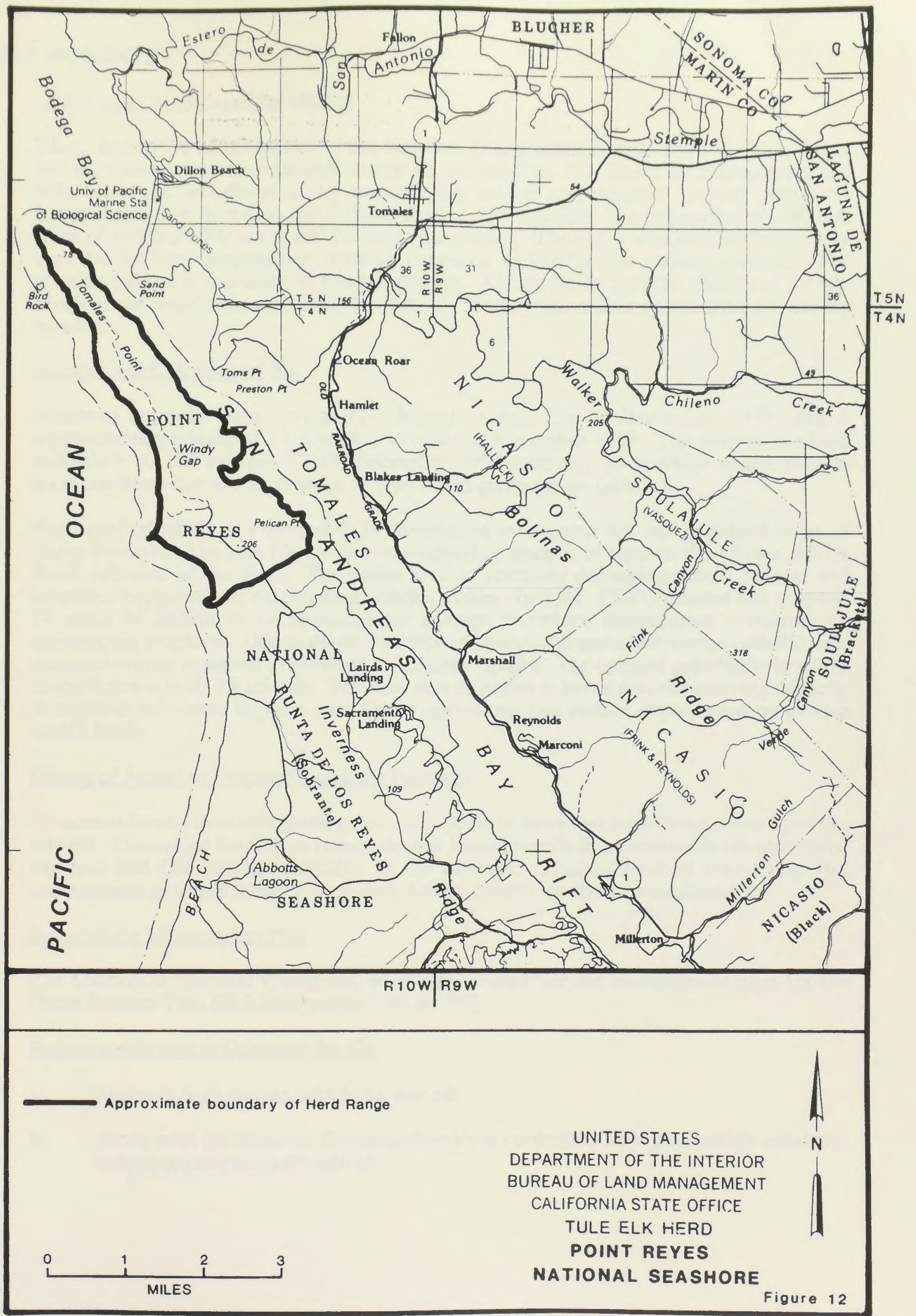





\section{CAMP ROBERTS}

1. Nature and Condition of the Habitat

Camp Roberts is administered by the National Guard under license from the U.S. Army and has extensive acreage suitable as tule elk habitat (Fig. 13). There are rolling grassland hills with oak woodland along north-facing slopes and riparian growth along the Nacimiento, San Antonio, and Salinas Rivers. This facility has approximately 40,000 acres of which 25,000 are leased for livestock grazing. The entire area is either intensively used for military purposes or is dense chaparral unsuitable for grazing animals. The riparian habitat is currently in good condition. Alfalfa fields provide additional forage. Much of the grassland is burned off or heavily used by the military during the crucial dry months.

\section{Number and Condition of Elk}

Nineteen animals were originally released at this site in December 1978, and a supplementary release of 13 animals was made in November 1983. The most recent herd estimate is 90-100 animals (CDFG December, 1990 estimate), all of which appear to be in good condition due to the presence of year-round green forage (alfalfa).

High quality habitat is expected to be maintained throughout the oak grassland areas of Camp Roberts. The tule elk spend a considerable amount of time in the private alfalfa fields adjacent to the Post. The entire herd is currently damaging crops, fences, and irrigation equipment on neighboring alfalfa ranches. In 1987, CDFG planted and irrigated 14 acres of alfalfa in an unsuccessful attempt to reduce depredation problems on surrounding cropland. Due to the availability of year-round succulent forage (alfalfa), tule elk numbers are expected to continue to increase rapidly. The optimal population level for Camp Roberts is $60-75$ animals. The herd size objective is lower than the carrying capacity in order to minimize impacts on military operations and reduce depredation on private alfalfa fields.

3. Effects of Actual or Proposed Land-use Practices

At current levels, livestock grazing does not appear to have had an adverse effect upon the tule elk. Controlled burning to reduce the fire hazard results in a decrease in the amount of summer and fall habitat available to the tule elk. Due to Federal ownership and management of Camp Roberts, long-term habitat conditions should remain stable.

\section{Status of the Management Plan}

The California National Guard and the CDFG completed the management plan for the Camp Roberts Tule Elk Management Unit in 1988.

5. Recommendations to Conserve the Elk

a. Maintain high-quality habitat for tule elk.

b. Work with the National Guard to develop a controlled burn plan which considers habitat requirements for tule elk. 



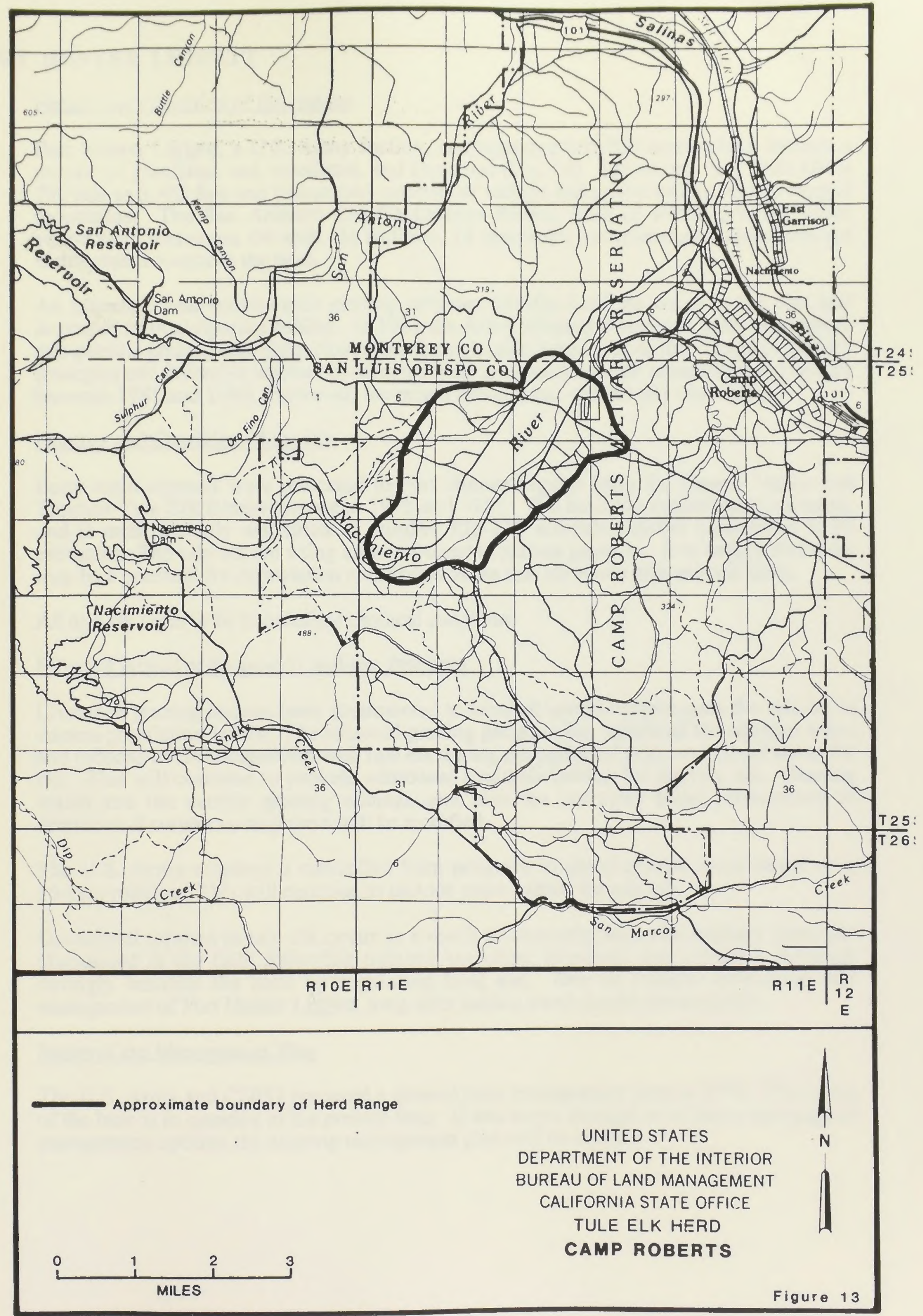





\section{FORT HUNTER LIGGETT}

\section{Nature and Condition of the Habitat}

Fort Hunter Liggett, a U.S. Army facility, encompasses 165,000 acres which include a mosaic of grassland, oak woodland, and chaparral (Fig. 14). Elevations vary from about 780 feet to 3,480 feet and topography consists of valleys and gentle rolling hills to rugged mountains. The San Antonio and Nacimiento Rivers, both of which provide water year-round, transverse the area. In addition, 14 reservoirs and numerous catchments are distributed throughout the base.

An intensive year-round cattle grazing program heavily used the range in the past and degraded critical riparian habitat. In 1981 the Army adopted a seasonal grazing program that permits grazing only from November through early June. Due to the change in grazing strategies and favorable weather conditions, most grassland-riparian areas improved rapidly between 1981 and 1986. However, the recent drought has slowed this recovery.

\section{Number and Condition of the Elk}

Forty-eight animals were relocated to Fort Hunter Liggett from the Owens Valley and Tupman Tule Elk Reserve between 1978 and 1981. The herd has continued to increase, and is most recently estimated to number 125-175 animals (CDFG December, 1990 estimate). The tule elk are using areas adjacent to private pastures. It is anticipated there may be a potential for depredation complaints as the tule elk move onto private lands.

All tule elk seem to be in excellent physical condition.

\section{Effect of Actual or Proposed Land-use Practices}

Livestock grazing has not been documented to have an adverse effect upon the tule elk at current population levels. The seasonal grazing program has enhanced the riparian zones and reduced cattle competition with tule elk during the period of peak nutritional stress for elk. This will continue to provide additional available habitat for the tule elk. Grazing leases and the current grazing management plan are currently being reexamined to determine if current management will be modified.

The U.S. Army employs a controlled burn program in the chaparral areas based on a 15-year rotation. This will continue to provide more habitat for tule elk.

Occasional injuries to tule elk occur as a result of entanglement with military materials abandoned in the field following training exercises; however, the military's presence strongly benefits the herd by regulating land use. Due to Federal ownership and management of Fort Hunter Liggett, long-term habitat trend should remain stable.

\section{Status of the Management Plan}

The U.S. Army and CDFG prepared a general herd management plan in 1979. The status of the base is in question at the present time. If this status changes to increase the range of management options, the existing management plan will be revised. 



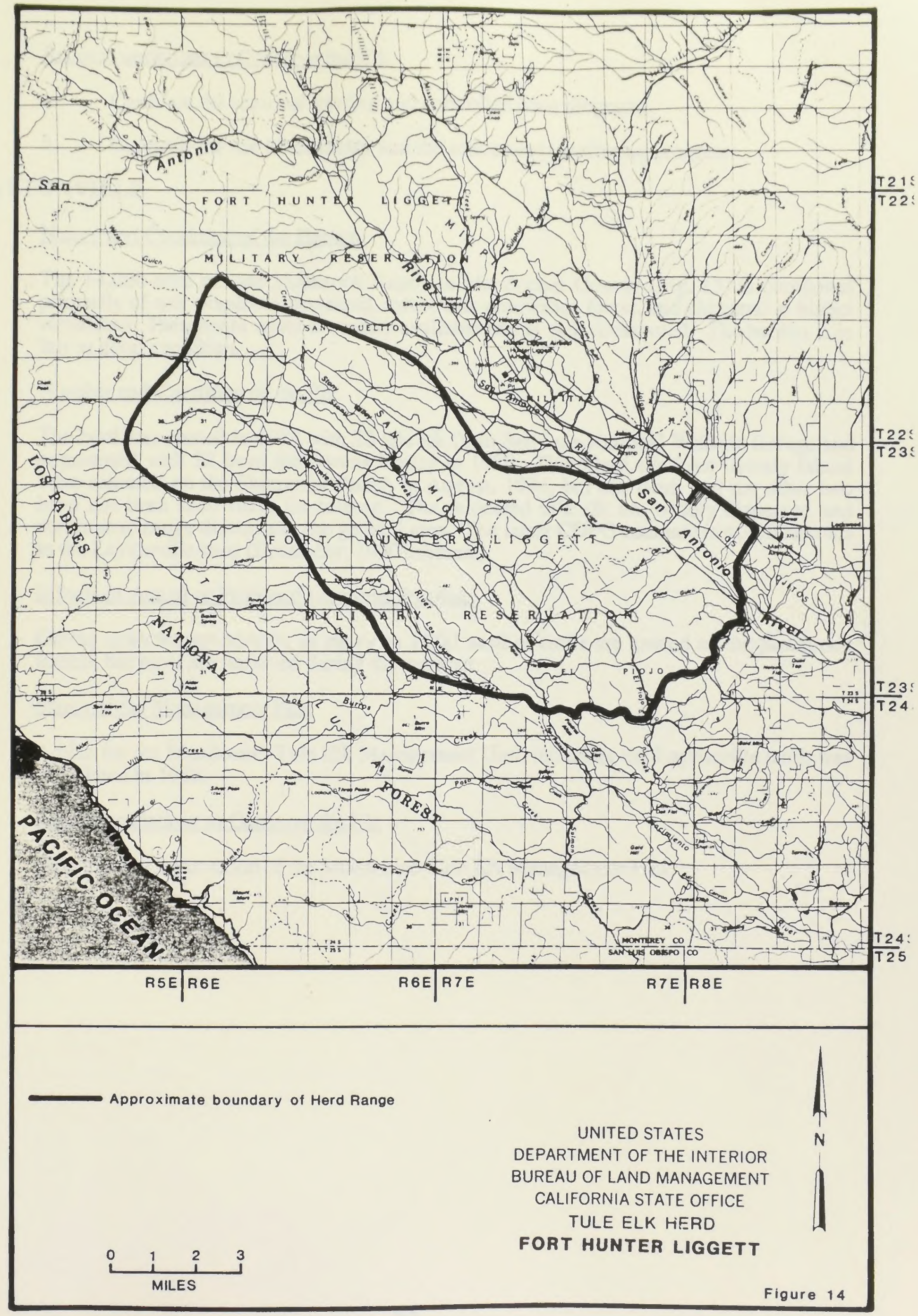



5. Recommendations to Conserve the Elk

a. Continue the seasonal grazing and controlled burn programs.

b. Continue the use of telemetry and the active herd monitoring program.

\section{LAYTONVILLE}

1. Nature and Condition of the Habitat

The 14,000-acre private Shamrock Ranch in Mendocino County (Fig. 15) is composed primarily of oak woodland-grassland, mixed oak-coniferous forest, and chaparral at higher elevations. Permanent water is readily available and is well distributed. The habitat is in fair to good condition.

2. Number and Condition of the Elk

The herd was started in 1979 with 20 tule elk from San Luis National Wildlife Refuge and augmented with 22 from the Owens Valley in 1980. Three bull elk from Grizzly Island were released on the Shamrock Ranch in August, 1984, but one died, and the other two have not been seen since the release. The relocated tule elk are widely dispersed and continue to range throughout the general area. The latest CDFG estimate is $40-50$ animals in the Laytonville herd (December, 1990 estimate).

3. Effects of Actual or Proposed Land-use Practices

During peak forage periods, as many as 3,000 head of cattle are grazed on the Shamrock Ranch, but most are removed during the summer.

4. Status of the Management Plan

A plan for the Mendocino Tule Elk Management Unit, including the Laytonville herd, was completed in 1988.

5. Recommendations to Conserve the Elk

Continue implementation of the Mendocino Tule Elk Management Plan. 



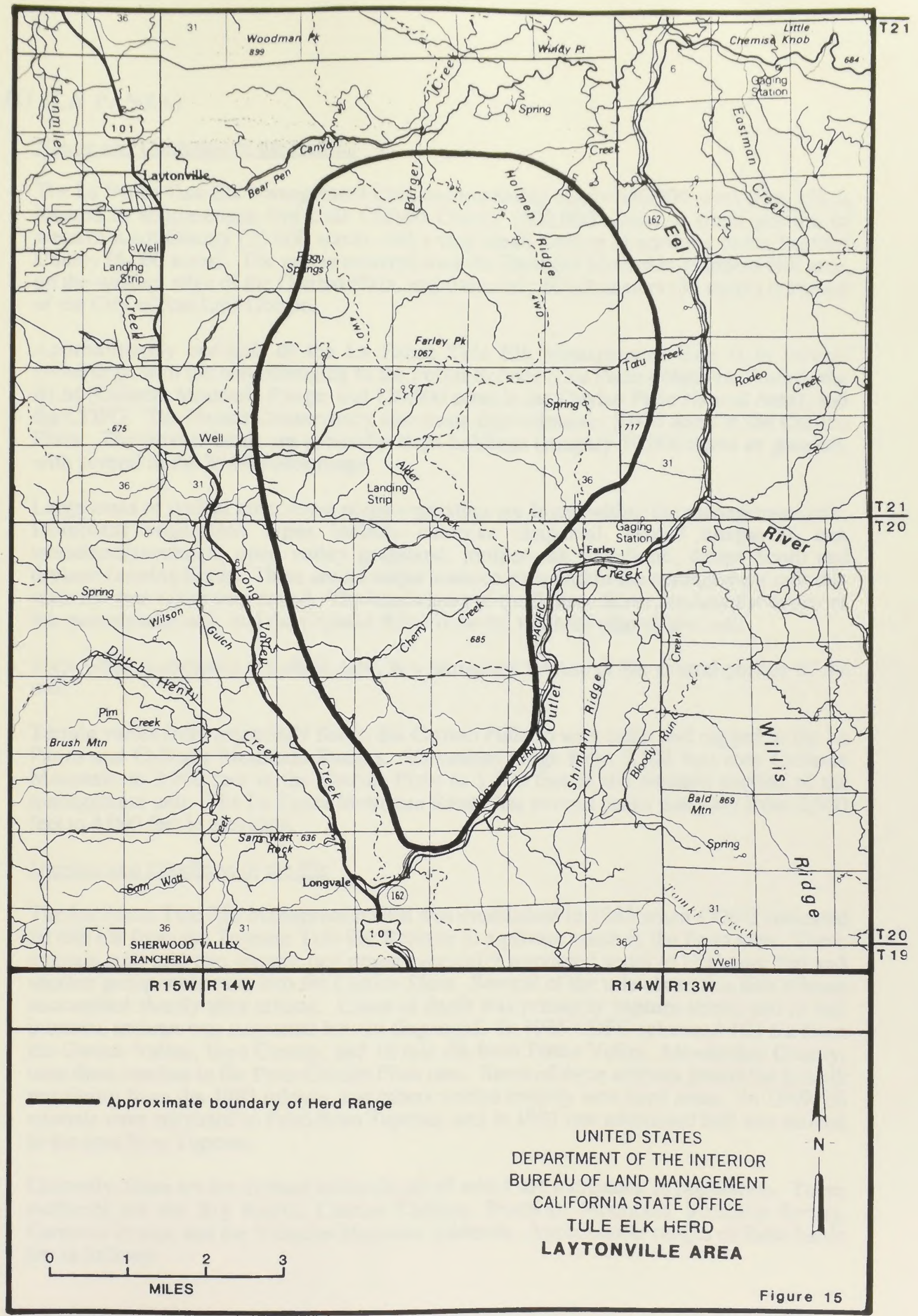



1. Nature and Condition of the Habitat

The La Panza Tule Elk Management Unit, encompassing nearly 640,000 acres (Fig. 16), is located in southeastern San Luis Obispo County $(600,000$ acres), a small portion of western Kern County (35,000 acres), and a very small portion of northern Santa Barbara County (5,000 acres). The unit is centered over the Freeborn Mountain-Hubbard Hill area, on the western edge of the Carrizo Plain, approximately 60 kilometers (35 miles) northeast of the City of San Luis Obispo.

Approximately one-half of the La Panza Tule Elk Management Unit is in private ownership, with the rest belonging to the Forest Service (Los Padres National Forest), the BLM (Caliente Mountain Range, and 120,000 acres in the Carrizo Plain Natural Area), and the CDFG. The Nature Conservancy also owns approximately 5,000 acres in the Carrizo Plain. The private lands are generally large holdings (roughly 10,000 acres or greater), with several in the 25,000 -acre range.

Large areas of typical inner coast range vegetation are found within the management unit. Dominant vegetation types include chamise chaparral, mixed chaparral, oak woodland/savannah, open valley grassland, juniper-oak woodland, desert scrub and dryland farming fields. There are no major watercourses within the management unit that maintain free water year-round. The headwaters of the Salinas River are near the center of the management unit, and the Cuyama River is on the southern edge of the unit.

Soda Lake, a normally dry alkali sink, is a prominent feature of the central portion of the unit.

Terrain varies from essentially flat in the Carrizo Plain to very steep and rugged in the La Panza and Caliente Mountain Ranges. Elevations range from 5,108 feet atop Caliente Mountain to 2,000 feet in the Carrizo Plain to 1,500 feet in the western portion of the management unit. The La Panza Mountain Range has several peaks that vary from 2,500 feet to 4,000 feet in elevation.

\section{Number and Condition of the Elk}

The La Panza Tule Elk Management Unit was established in 1983 when CDFG relocated 20 tule elk from the Tupman Tule Elk Reserve to a private ranch in the Pozo area. These animals split into two groups; one group eventually wandered south to Highway 166 and another group went east, into the Carrizo Plain. Several of the tule elk in this first release succumbed shortly after release. Cause of death was primarily capture stress, and in one instance, anthrax was suspected but not diagnosed. In 1985 CDFG relocated 103 elk from the Owens Valley, Inyo County, and 16 tule elk from Potter Valley, Mendocino County, onto three ranches in the Pozo-Carrizo Plain area. Some of these animals joined the tule elk remaining from the 1983 release, and others started entirely new herd areas. In 1989, 36 animals were relocated to Pozo from Tupman, and in 1991 one additional bull was moved to the area from Tupman.

Currently, there are six distinct subherds, all of which are increasing in population. These subherds are the Big Rocks, Carrizo Canyon, Freeborn Mountain, Mustang Spring, Carneros Rocks, and the Yeaguas Mountain subherds. Approximate ranges of these herds are as follows: 



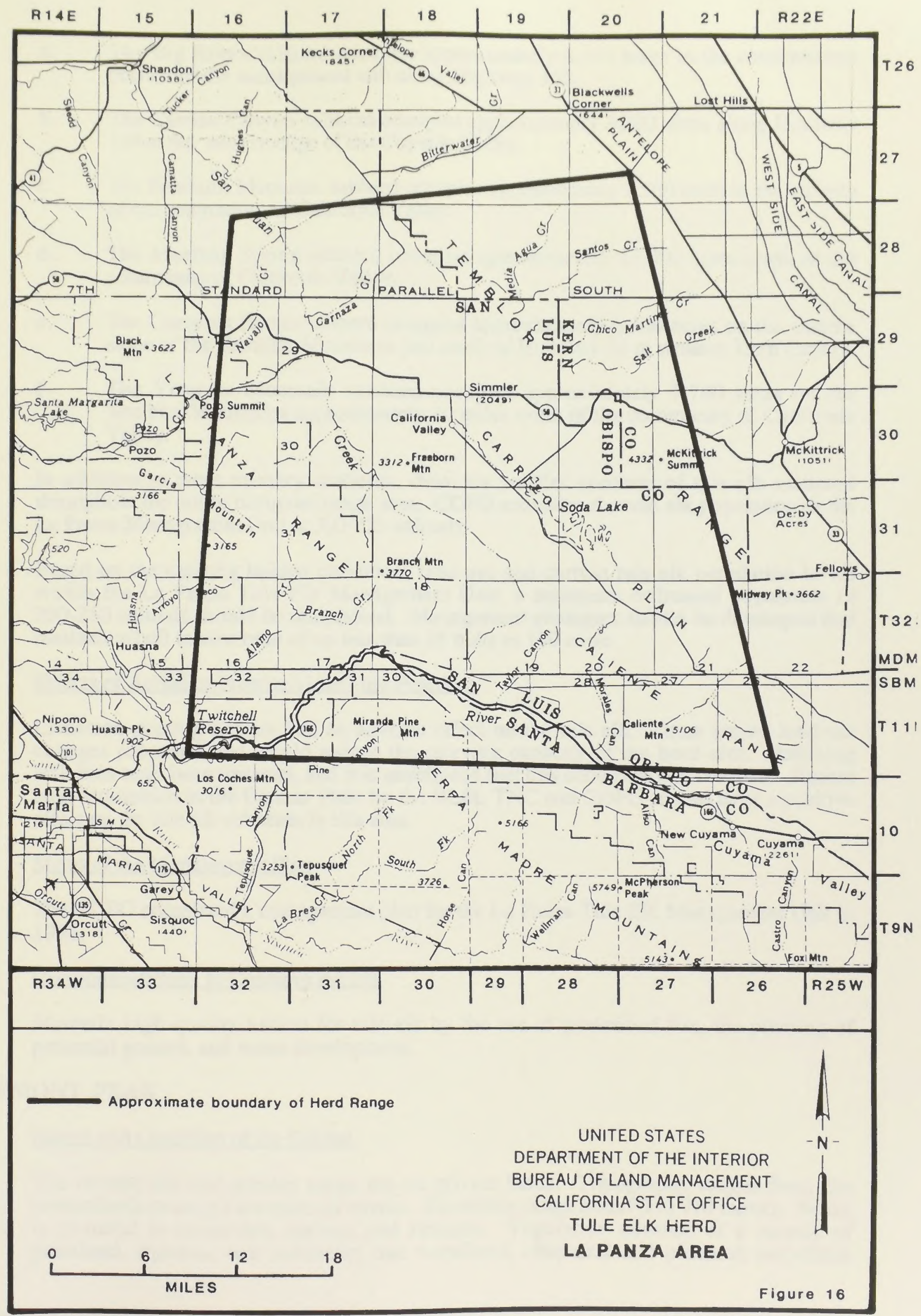



a. The Big Rocks subherd occupies approximately 4,450 acres in the southwestern portion of the management unit along Highway 166.

b. The Carrizo Canyon subherd occupies approximately 3,200 acres along Highway 166 at the western edge of the Cuyama Valley.

c. The Freeborn Mountain subherd occupies approximately 2,500 acres in the vicinity of the community of California Valley.

d. The Mustang Spring subherd occupies approximately 19,000 acres north of the community of California Valley.

e. The Carneros Rocks subherd occupies approximately 6,400 acres on the eastern slope of the Temblor Mountains just north of Highway 58 in western Kern County.

f. The Yeaguas Mountain subherd occupies approximately 7,700 acres on the Temblor Mountains approximately 10 miles north of the community of California Valley.

In addition to these primary subherds, there are smaller numbers of tule elk scattered throughout the entire occupied range area. CDFG estimates the tule elk population of the La Panza Management Unit at 300-325 animals.

Based on the existing habitat condition, land use and current tule elk population levels within the La Panza Tule Elk Management Unit, a minimum estimated population of 200-250 animals should be maintained. Management strategies should be developed that maintain a bull to cow ratio of no less than 25 bulls to 100 cows.

3. Effects of Actual or Proposed Land-use Practices

Livestock grazing has not had an adverse effect on the tule elk. There are no land-use changes proposed that would reduce the carrying capacity of the herd area. Poaching activities have been minimal, and it is anticipated that this condition will continue. Recent land acquisition in the Carrizo Plain by the BLM, TNC and CDFG should have a positive effect on the tule elk subherds in this area.

4. Status of the Management Plan

The CDFG completed a management plan for the La Panza Tule Elk Management Unit in 1988.

5. Recommendations to Conserve the Elk

Maintain high quality habitat for tule elk by the use of prescribed fire, the planting of perennial grasses, and water development.

\section{FREMONT PEAK}

1. Nature and Condition of the Habitat

The release site and present range are on private lands. Topography ranges from flat bottomlands to steep mountainous terrain. Elevations range from 70 to 970 meters. Water is plentiful in reservoirs, springs and streams. Vegetation consists of a mosaic of grassland, riparian, oak savannah, oak woodland, chaparral and pine/oak woodland. 

Primary uses of the land are livestock grazing and limited hunting. Most of the tule elk now stay west of the 10,000-acre Reeves Ranch release site, on the adjacent 11,000-acre Silacci Ranch (Fig. 17). However, tule elk occasionally move out into the Salinas Valley floor, and have caused some damage to agricultural crops and fences.

2. Number and Condition of Elk

Twenty animals ( 7 bulls and 13 cows) were originally released at this site in November 1983. One collared bull from the original release traveled 20 airline miles across Highway 101 to Carmel Valley. He later returned and was found dead near the original release site. The carcass was located by "mortality mode" signals from the radio collar. This herd was hunted for the first time in 1990 when six mature bulls were removed. The latest population estimate from CDFG is 50-60 animals (December, 1990 estimate).

The tule elk appear to be in excellent condition.

3. Effects of Actual or Proposed Land-use Practices

Livestock grazing can compete with tule elk for both forage and space. Elk tend to avoid large congregated numbers of livestock. The Silacci Ranch usually brings cattle onto the range in December and removes them in June. This practice greatly reduces the potential for conflict with tule elk.

4. Status of the Management Plan

The CDFG completed the management plan for the Fremont Peak Tule Elk Management Unit in 1988.

5. Recommendations to Conserve the Elk

a. Continue present use of seasonal livestock grazing to preserve high-quality habitat.

b. Develop means to alleviate depredation so range expansions would be well received by adjoining landowners. 



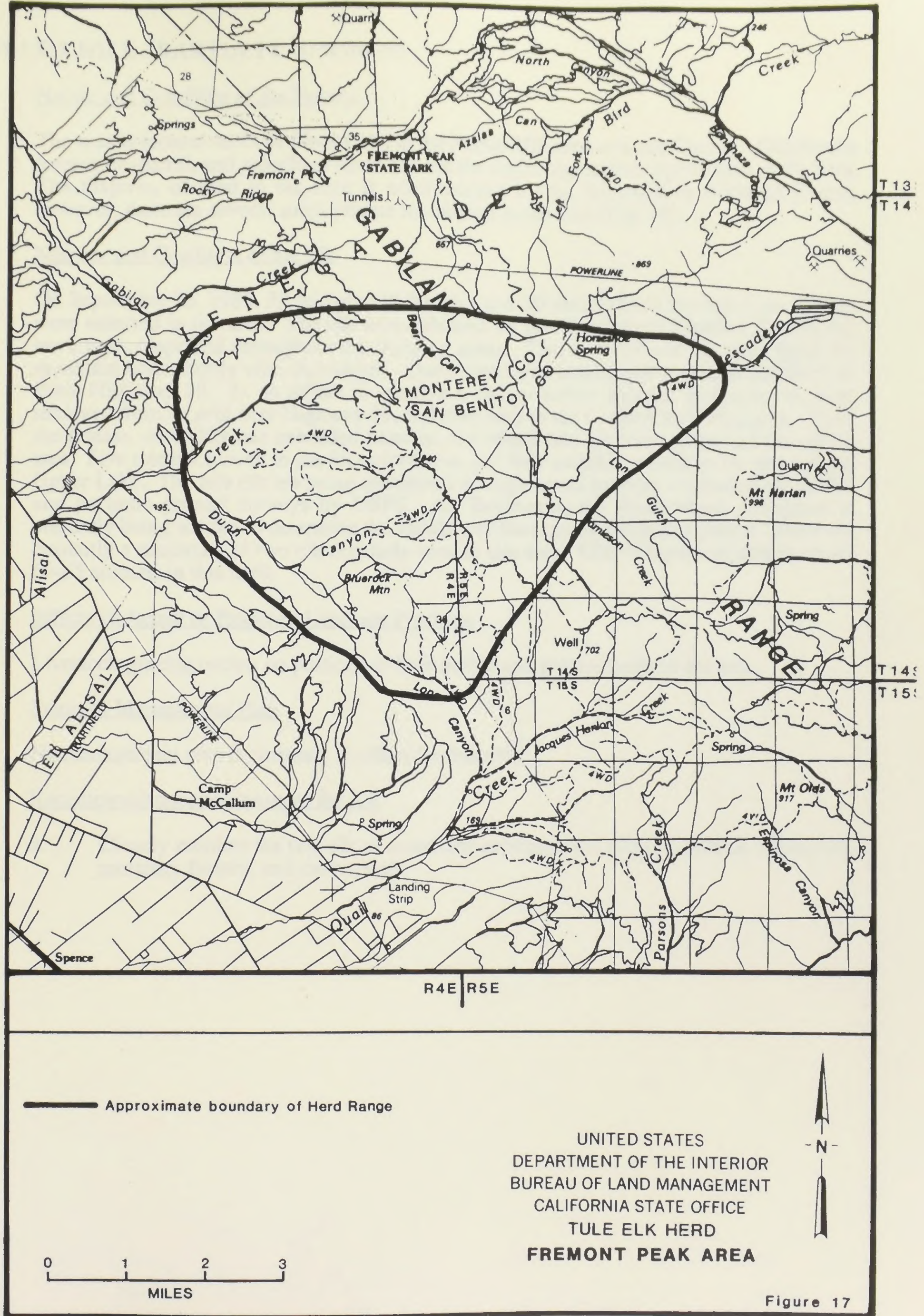





\section{POTATO HILL (BARTLETT SPRINGS)}

\section{Nature and Condition of the Habitat}

The area is located north of Clear Lake in the Potato Hill area of Lake County. Coniferous forests, chaparral, and woodland savannah are the major vegetation types found in the area. The majority of land in the area is administered by the Mendocino National Forest, however, there are several small private inholdings in the area (Fig. 18).

2. Number and Condition of the Elk

On September 26, 1985, 59 tule elk (39 females and 20 males) from the San Luis Refuge were released in the area. The elk were released on the Mendocino National Forest, but have since dispersed throughout the outlying areas. Two to three tule elk were taken by mountain lions shortly after the release. One animal was involved in a vehicle accident on State Highway 29. In an effort to remove a public safety hazard, five tule elk were removed from an area near Highway 29, and relocated in the Cache Creek herd area. Since the release, mortality has exceeded natality, and many tule elk have dispersed out of the area. Five tule elk moved to the Stonyford area, and four animals moved to the area around Upper Lake. The tule elk are being monitored through aerial surveys conducted by CDFG and periodic ground surveys by USFS. An Environmental Assessment document is presently being written to determine the viability of having tule elk on the Forest. There are currently a minimum of two elk regularly seen in this area. CDFG estimates that there are 60-65 animals in this herd.

3. Effects of Actual or Proposed Land-use Practices

Livestock grazing occurs on portions of both public and private lands in the area.

4. Status of Management Plan

No management plan is currently in effect for this area.

5. Recommendations to Conserve the Elk

a. Closely monitor the tule elk to determine reproductive success, habitat utilization, mortality factors, and movements. 



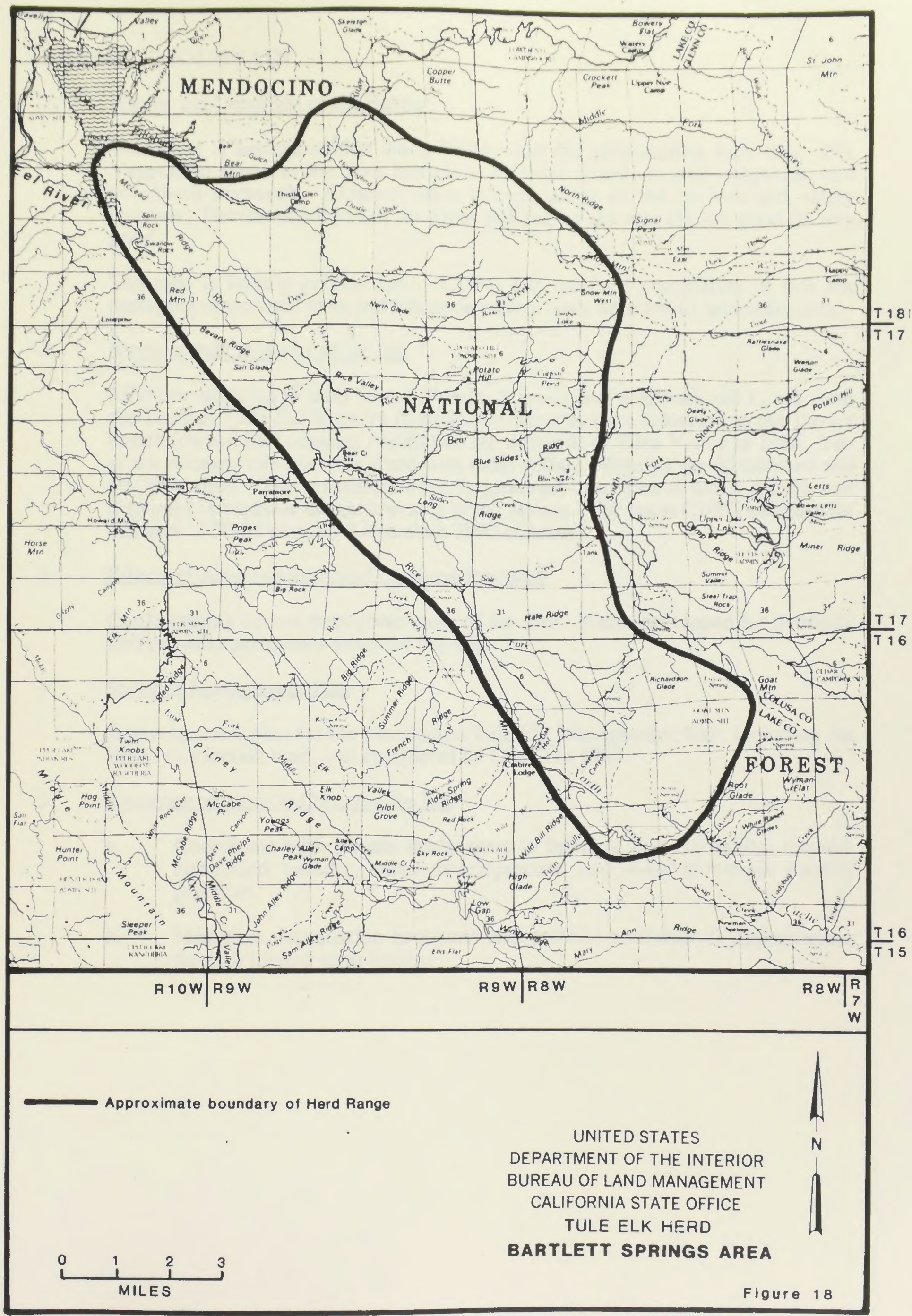





\section{BRUSHY MOUNTAIN}

1. Nature and Condition of the Habitat

This herd is located within Eden Valley and the surrounding hills (Fig. 19). Vegetation types in the area include coniferous forest, coastal chaparral, and woodland savannah. Riparian areas occupy many of the ravines and valley bottoms. Habitat condition in the areas utilized by the tule elk are good to very good.

The area is largely private land. CDFG has received complaints of tule elk damaging ornamental trees and fences on private lands adjacent to the release area.

2. Number and Condition of the Elk

Nineteen elk from Grizzly Island ( 5 bulls, 8 cows, and 6 calves) and 11 elk from the Tupman Tule Elk Reserve (6 bulls and 5 cows) were relocated to the Baxter Ranch (owned by Louisiana Pacific) on the west side of Eden Valley in 1986. Ten of the released tule elk were fitted with radio collars. Eight of the 30 released tule elk have died. The remainder have fragmented into several small groups and dispersed throughout the general area of the release. The latest CDFG estimate for this herd is 30-35 animals (December, 1990 estimate).

3. Effects of Actual or Proposed Land-use Practices

Cattle grazing occurs throughout most of the area. Water developed for livestock also provides permanent water for tule elk.

4. Status of Management Plan

A management plan for the Mendocino Tule Elk Management Unit, including the Brushy Mountain herd, was completed by CDFG in 1988.

5. Recommendations to Conserve the Elk

a. Coordinate with private landowners to improve tule elk habitat through controlled burning, water developments, and sound livestock grazing practices.

b. Minimize depredation problems and provide recreational opportunities through limited sport hunting. 



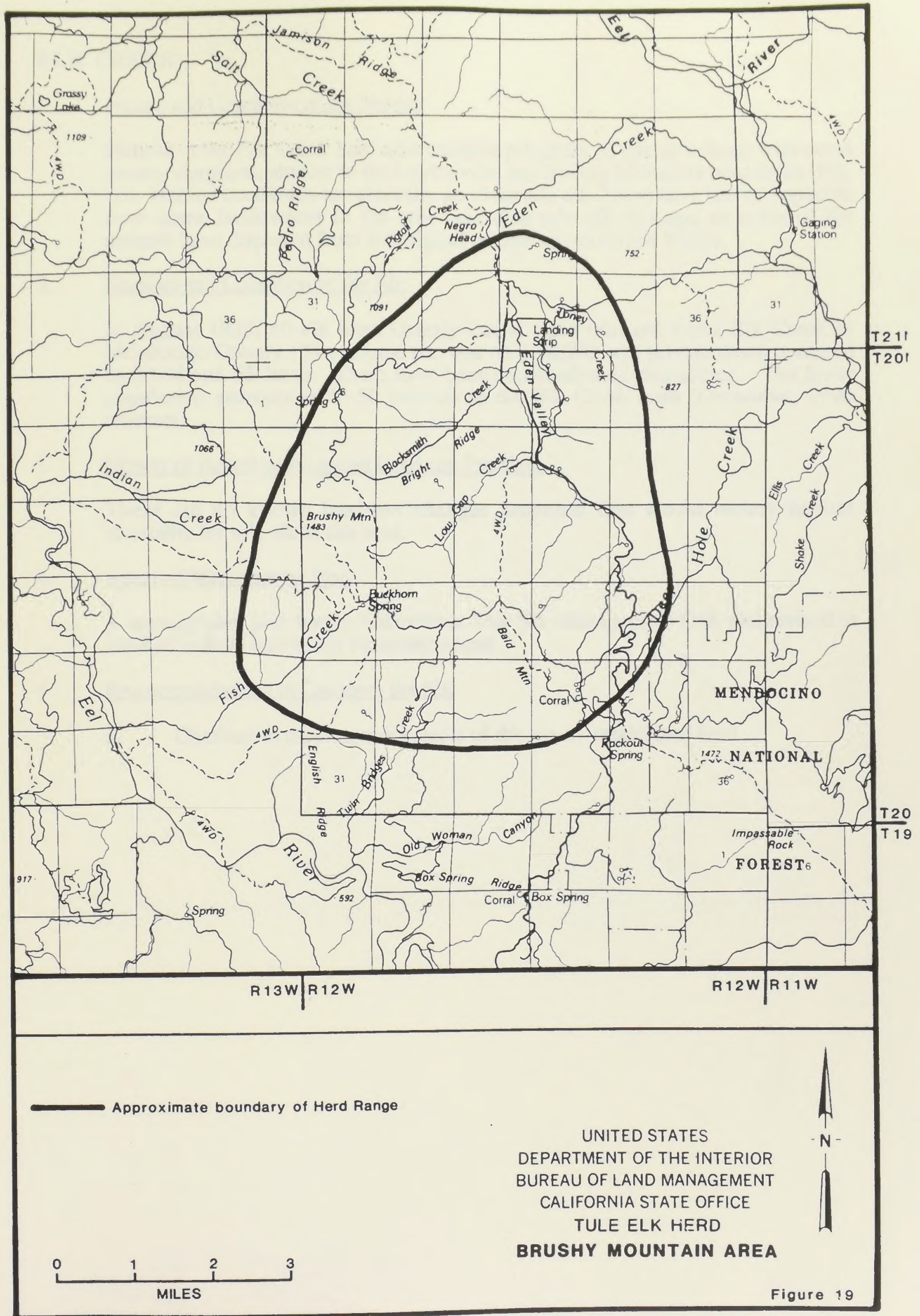





\section{ELK CREEK}

1. Nature and Condition of the Habitat

Habitat in the Elk Creek herd area consists primarily of oak woodland with some brushy chaparral, similar to the Laytonville and Brushy Mountain herd areas (Fig. 20). Habitat conditions are generally good for tule elk. There have been complaints from some landowners in the area regarding tule elk damage, as some of the animals have dispersed from the original release site to Round Valley.

2. Number and Condition of the Elk

In August 1988, 40 elk from Grizzly Island were released along Elk Creek in Mendocino County. The release site was on a 28,000 -acre private ranch bordered by BLM and FS lands. There have been two confirmed mortalities. The latest population estimate is 40-50 animals in the Elk Creek herd (December, 1990 estimate).

3. Effects of Actual or Proposed Land-use Practices

These are no known land-use changes proposed that would reduce habitat suitability for tule elk in this area.

4. Status of Management Plan

A management plan for the Mendocino Tule Elk Management Unit was revised in 1988 to include this newly established herd.

5. Recommendations to Conserve the Elk

a. Continue to monitor movements of this newly established herd. 



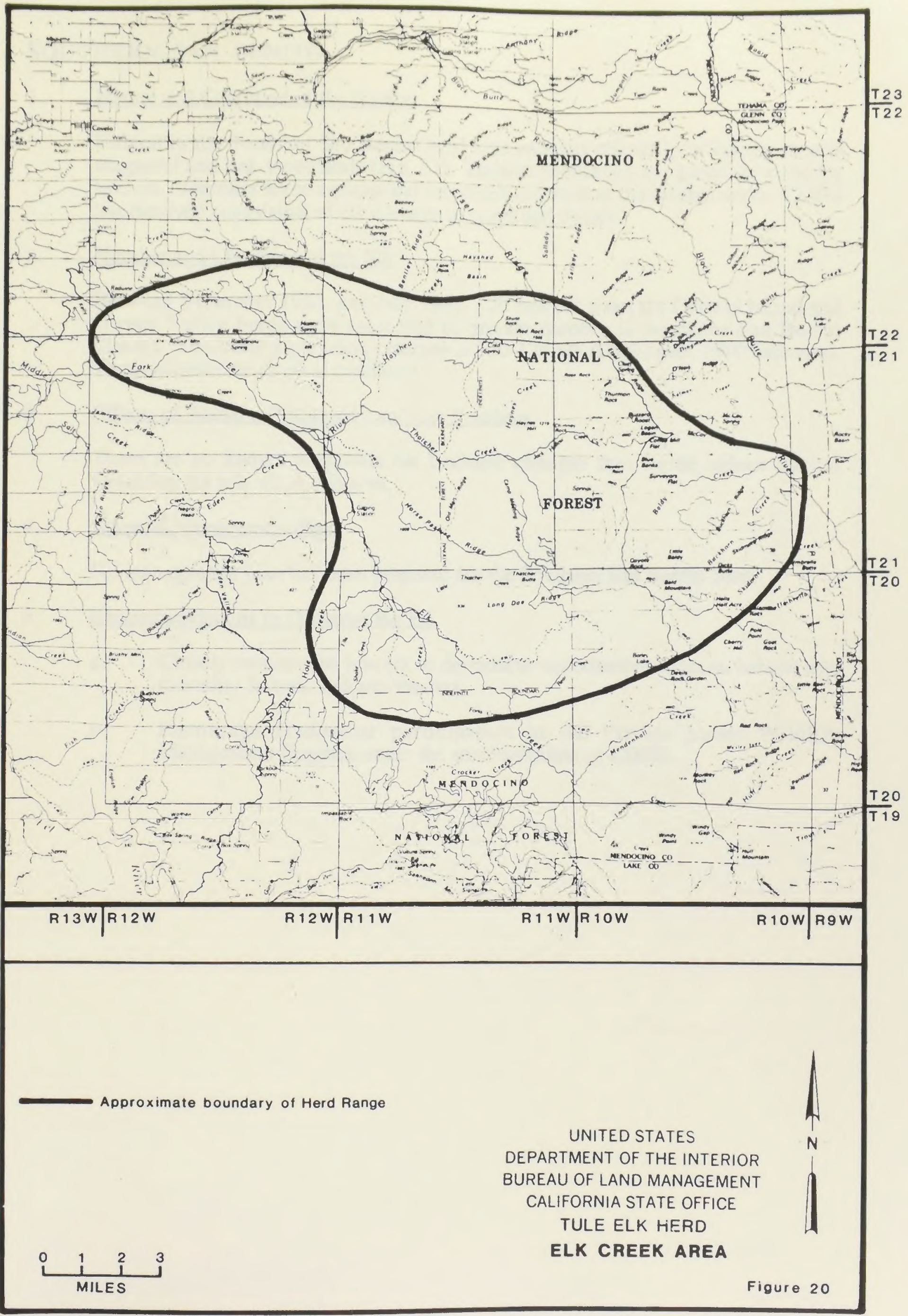





\section{SOUTHERN SAN BENITO}

1. Nature and Condition of the Habitat

Habitat in the Southern San Benito herd area consists primarily of brushy coastal chaparral and oak-woodlands (Fig. 21). Habitat conditions are generally good for tule elk. Thereare some agricultural croplands adjacent to the release areas. CDFG has received complaints of elk damage to crops and fences.

2. Number and Condition of the Elk

Between December 1985, and July 1986, 120 tule elk from the Grizzly Island and Owens Valley herds were relocated to private ranches in Southern San Benito County. The latest population estimate is 100-125 elk (December, 1990 estimate). These animals are in good condition.

3. Effects of Actual or Proposed Land-use Practices

There are no known proposals for land-use changes that would reduce habitat suitability for tule elk in this area.

4. Status of Management Plan

No management plan has been prepared for the Southern San Benito herd.

5. Recommendations to Conserve the Elk

a. Closely monitor the tule elk to determine reproductive success, habitat use, mortality factors, and movements.

b. Encourage landowner participation in the Private Lands Wildlife Management Program under the administration of CDFG. 



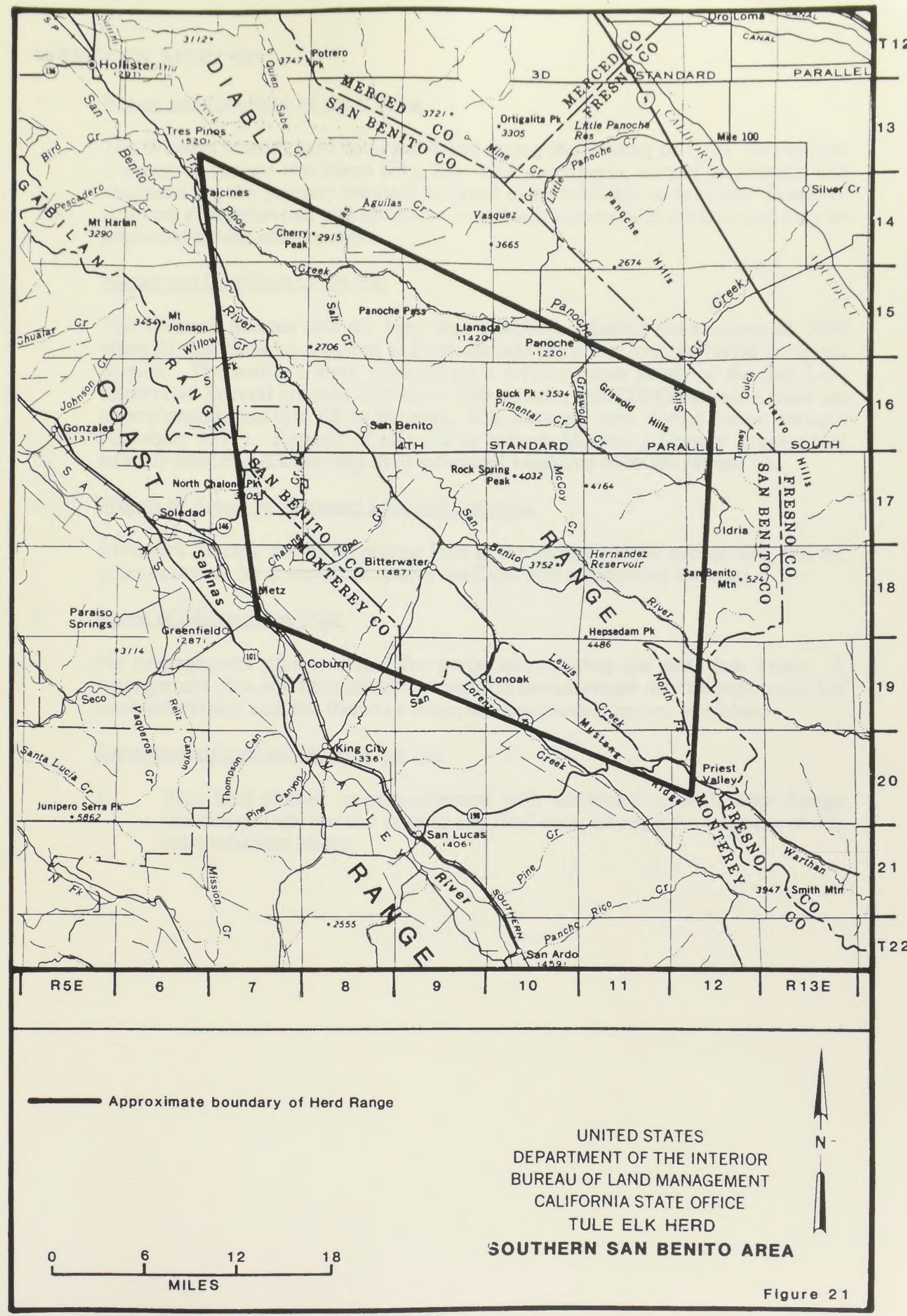





\section{WESTERN MERCED}

1. Nature and Condition of the Habitat

The Western Merced herd was established during the summer of 1990. The release site was on private ranchland (Fig. 22). Oak woodlands, annual grasslands, and chaparral are the primary habitats believed to be available to tule elk. Scattered stringers of riparian oak and sycamore woodlands also exist in the area and may be important habitat components.

2. Nature and Condition of the Elk

The Western Merced tule elk herd was established during the summer of 1990 when 21 tule elk were captured and translocated from the Concord Naval Weapons Station. The animals were released on a private ranch south of the San Luis Reservoir. Several animals died since their release, and CDFG estimates there are approximately ten tule elk in the area. Elk were not seen during recent surveys (October, 1991). Reports of tule elk in eastern Monterey County suggest that animals from this release may have wandered westward from the release site.

3. Effects of Actual or Proposed Land-use Practices

Livestock grazing occurs on private land in the vicinity of the release site, and the potential exists for competition and/or conflicts with agricultural interests.

4. Status of Management Plan

No management plan is slated for preparation during the next few years. A management plan will be considered when it is demonstrated that the population has established itself and that there is a range of management options available.

5. Recommendations to Conserve the Elk

a. This herd should be supplemented with additional animals after forage conditions improve and prior to any final decision regarding success of this reintroduction effort. 



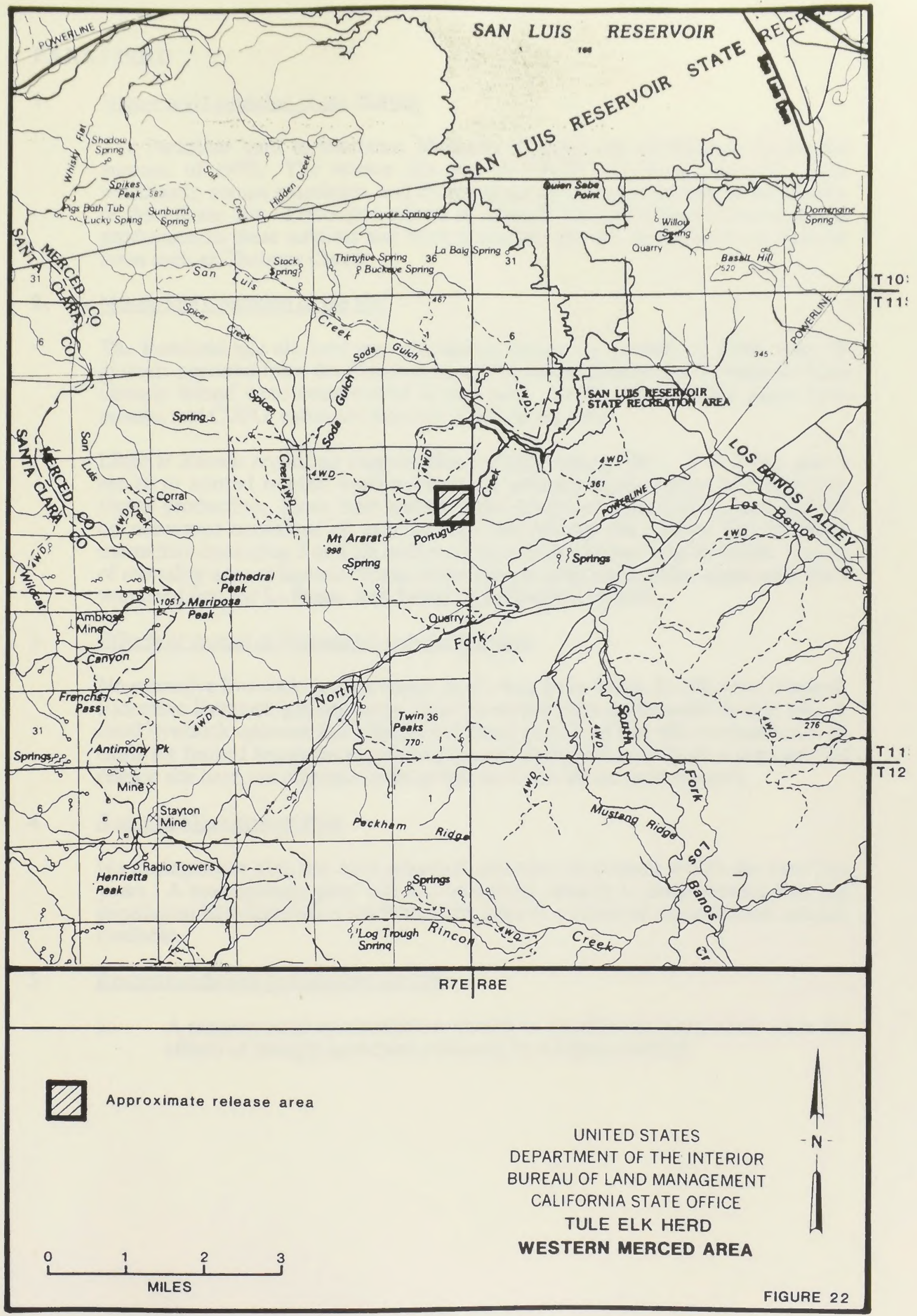





\section{PARKFIELD}

\section{Nature and Condition of the Habitat}

The Parkfield herd in southeast Monterey County was established during the summer of 1990. The release site was on private ranchland (Fig. 23). Oak woodlands, annual grasslands, and chaparral are the primary habitats in the vicinity of the release site. Prolonged effects of drought have adversely affected forage production in these habitats and have increased tule elk dependence on riparian areas such as Cholame Creek.

2. Nature and Condition of the Elk

The Parkfield tule elk herd was established during the summer of 1990 when 32 animals captured from the Concord Naval Weapons Station and 11 animals from Grizzly Island were translocated to this area. Seven animals died since their release, and CDFG estimates there are 37 elk in the area.

Little is known regarding reproductive success during 1991. It is likely that a return to normal rainfall conditions would enhance reproduction by improving forage production. Since their release, small groups of tule elk have been sighted on numerous occasions on ranches near the release site. Some five to seven mortalities (including 3 of 6 elk with radio transmitters) have been detected. Causes of mortality are not known. Some of the tule elk with transmitters apparently have wandered into the La Panza area, based on radiotelemetry data.

3. Effects of Actual or Proposed Land-use Practices

No extensive livestock grazing occurs at the area from which the elk were released. Extensive livestock grazing could result in competition unfavorable to tule elk. A local livestock operator has complained about perceived tule elk competition with cattle for limited forage during a drought year. However, most landowners near the release site have not objected to the presence of tule elk on their property.

\section{Status of Management Plan}

No management plan has been prepared, and none is planned within the next few years. A management plan will be considered when it is demonstrated that the population has established itself and that there is a range of management options available.

\section{Recommendations to Conserve the Elk}

a. A supplemental reintroduction should be considered, particularly after the effects of drought have been mitigated by adequate rainfall. 



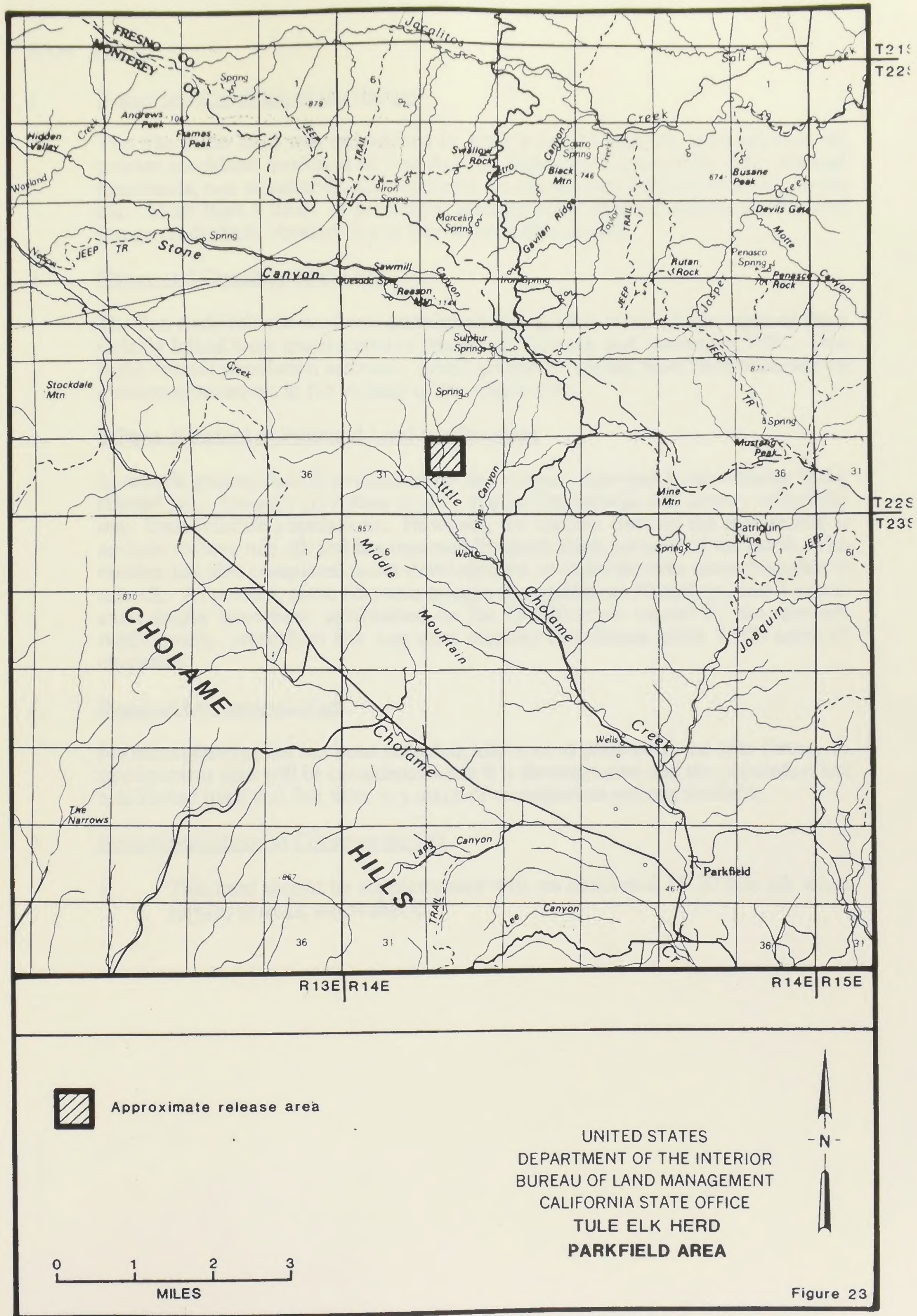





\section{SAN ARDO}

1. Nature and Condition of the Habitat

The San Ardo herd was established in 1991 when 13 tule elk were released on private ranchland southeast of San Ardo in Monterey County (Fig. 24). Annual grasslands, oak woodlands, and chaparral are the primary habitats available to the elk. More than 4 years of prolonged drought have affected habitat quality and forage production. Availability of free water is also limited.

\section{Nature and Condition of the Elk}

The San Ardo tule elk herd was established during 1991 when 13 elk captured from Grizzly Island were translocated to this area in October and November 1991. This is the current population estimate. Small groups of tule elk have been observed on numerous occasions in the vicinity of the release site.

\section{Effects of Actual or Proposed Land-use Practices}

Livestock grazing and oil production are two primary land uses in the vicinity of the release site. Drought (resulting in poor forage conditions) and water availability may limit wildlife populations. However, the rancher owning the release site is anxious to have tule elk and has removed livestock from portions of the ranch. The rancher has also completed water developments to make the area more desirable to tule elk. At present, some 65 water troughs, an additional 30 springs, and 8 ponds exist and/or have been established on the 13,000 acres owned by the rancher. Additionally, prescribed fire was used recently to enhance some 7,000 acres of chaparral.

\section{Status of Management Plan}

No management plan has been prepared, and none is planned in the near future. A management plan will be considered when it is demonstrated that the population has established itself and that there is a range of management options available.

\section{Recommendations to Conserve the Elk}

a. This herd should be supplemented with an additional 15-30 tule elk when surplus animals are available. 



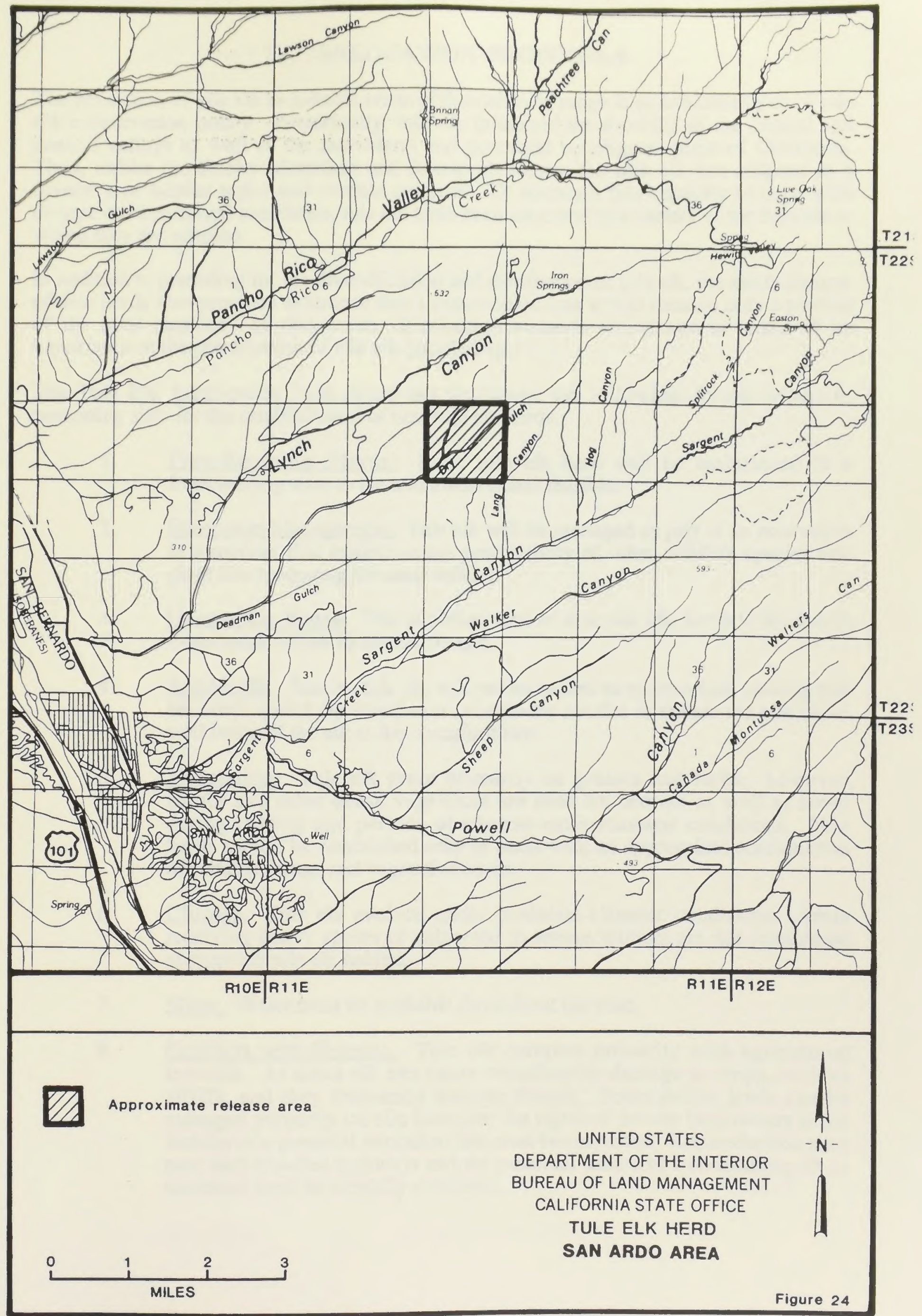





\section{RELOCATION PROPOSALS}

The relocation of tule elk to suitable areas of their historic range is an important part of tule elk conservation policy. Historically, tule elk inhabited the foothills of the central and coastal valleys as well as the marshland and perennial bunchgrass plain of California. Thus, unlike the Rocky Mountain and Roosevelt forms, the tule elk has adapted to a diversity of habitat types and climate patterns. To maintain this capacity to cope with diverse environmental conditions, tule elk have been relocated to a variety of the habitats to which they are adapted.

In addition to providing for the diversification and distribution of tule elk, the establishment of new herds also provides assurance that a catastrophic loss would remove only a portion of the total number. In this sense, distribution exceeds abundance in terms of its importance in the preservation of tule elk populations.

The Tule Elk Interagency Task Force has developed the following criteria to use in evaluating sites for the establishment of new tule elk herds:

1. Free-Roaming Herds, Each tule elk herd will be maintained in a free-roaming state to the maximum extent feasible.

2. Ecosystem Management. Tule elk will be managed as part of an ecosystem in a manner that maintains the productivity of other wildlife species and plant life occupying the same habitat.

3. Geographic Range. The establishment of new tule elk herds is limited to those areas within its historic range.

4. Surplus Elk. Surplus tule elk will not be moved to an area with existing tule elk herds unless the additional animals are needed to ensure the continued well being of the elk at the transplant site.

5. Vegetation, Tule elk graze primarily on grasses and forbs; however, shrubs and other dense vegetation are used for browse as well as cover during calving and periods of adverse environmental conditions. New herds should be established only in areas with an appropriate combination of suitable forage and vegetative cover.

6. Climate Tule elk evolved under moderate climatic conditions. Areas receiving heavy snows or subjected to severe winters are not considered appropriate tule elk habitat.

7. Water, Water must be available throughout the year.

8. Conflicts with Humans. Tule elk compete primarily with agricultural interests. At times elk can cause considerable damage to crops, such as alfalfa, and they frequently damage fences. Some public lands can be managed primarily for elk; however, the rights of private landowners in the vicinity of a potential relocation site must be respected. Reintroduction sites near well-traveled highways and the potential hazard of free-roaming elk to motorists must be carefully evaluated. 

9. Interaction with Deer. Where tule elk and deer ranges overlap, and both species use the available forage in a similar way, the potential for habitat degradation is increased. Consequently, the status of deer should be evaluated carefully in potential relocation areas.

10. Maintenance of Natural Populations. For aesthetic as well as economic reasons, tule elk should be reintroduced to areas where the natural vegetation can support the animals on a year-round basis.

11. Maintenance of Pure Stock. Tule elk should be reintroduced only in areas where there is no chance of contact with other subspecies of elk.

12. Public Enjoyment. A consideration in prioritizing areas for reintroduction will be the availability of public access for non-consumptive and/or consumptive use.

13. Maintenance of Populations within Established Goals. A consideration in prioritizing areas for reintroduction will be the availability of practical means of population management so that the herd can be maintained within its established population goals. Practical means include but are not limited to subsequent relocation of excess animals, hunting, and land acquisition to increase the carrying capacity of the range.

The Task Force has considered at least 46 potential relocation sites since 1977 . The following is a summary of the status of each potential release site.

1. Completed Successful Releases:

$\begin{array}{ll}\text { Point Reyes } & \text { Fremont Peak } \\ \text { San Luis } & \text { Laytonville } \\ \text { Cache Creek } & \text { Lake Pillsbury } \\ \text { Whitney } & \text { Concord } \\ \text { Tupman } & \text { Mt. Hamilton } \\ \text { Fort Hunter Ligget } & \text { Grizzly Island } \\ \text { Camp Roberts } & \text { Bartlett Springs } \\ \text { Pozo } & \text { Southern San Benito } \\ \text { Brushy Mountain } & \text { Elk Creek } \\ \text { Western Merced } & \text { Parkfield } \\ \text { San Ardo } & \end{array}$

2. Completed Unsuccessful Releases:

Jawbone Canyon

3. Rejected Proposals:

SITE

Saline Valley

Diamond Mountain

Jerusalem

\section{REASON FOR REJECTION}

Outside historic range, horse and cattle competition

Outside historic range, livestock competition

Mostly private land, local opposition 

Dos Rios

English Ridge

Pixley

Henry Coe State Park

Camp Pendleton

Rancho California

Warner Ranch

Los Flores

Fort Ord

Beale

Spenceville

Davenport Cement Co.

Chatsworth Reservoir

Golden Gate National

Recreation Area

(Tennessee Valley)

Vandenberg

Los Gatos Creek

Webb Track

Dye Creek Ranch

Inks Creek

Neary Ranch

Pete Anderson Ranch

Roberts Ranch

Ohlone Wilderness
Lack of suitable habitat

Too brushy

Local opposition

Mt. Hamilton herd is in the area, local opposition

Outside historic range

Adjacent residential development

Outside historic range

Outside historic range

Lack of suitable habitat, high potential for depredation conflicts, adjacent to residential area, lack of summer water, needs fence

Area too small, needs fence

Area too small, needs fence

Lack of suitable habitat

Lack of suitable habitat, outside historic range

Adjacent to urban development, needs fence

Conflicts with space shuttle program, potential depredation problems, and needs fence

Lack of suitable habitat

Small size, potential for depredation problems

Lack of suitable habitat, potential conflicts with agriculture

Lack of suitable habitat, potential conflicts with agriculture

Lack of suitable habitat, potential conflicts with agriculture

Local opposition, elk already in the area

Local opposition, potential for depredation problems

Small size, local landowner opposition

4. Proposal Currently Under Consideration (Fig. 25):

Bear Creek 



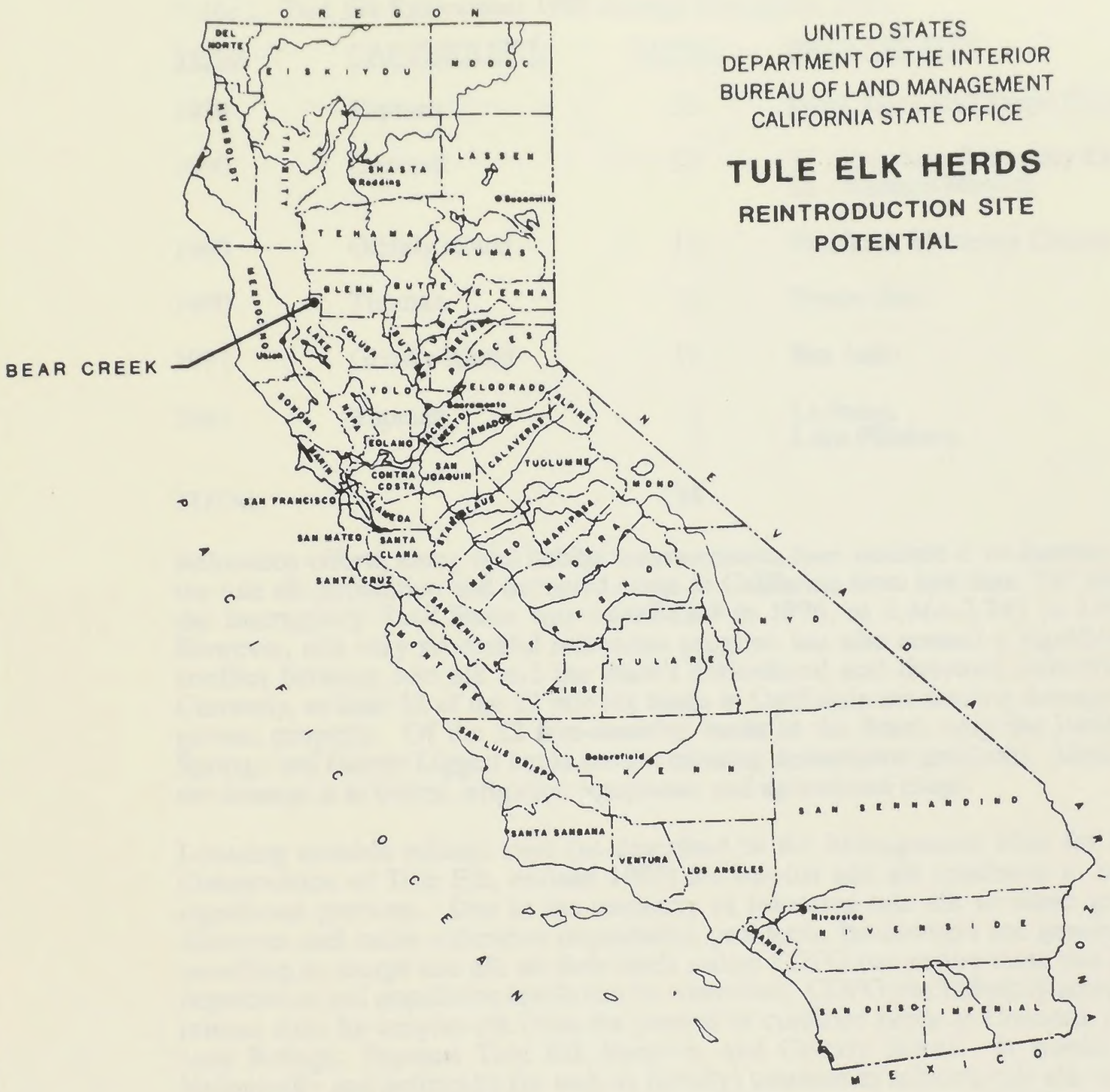

$21 \quad 2 \quad 28 \quad 30 \quad$ I8 $\quad 100 \quad 128 \quad 130 \quad 173 \quad 200$ 

5. Relocations Since 1989 Report to Congress:

Since the March 1989 Report to Congress, 117 elk have been relocated. Relocation efforts are summarized in Table 2. Three new tule elk herds have been established through these efforts:

Table 2. Tule Elk Relocations 1989 through November, 1991.

\begin{tabular}{|c|c|c|c|}
\hline YEAR & CAPTURE SITE & TOTAL & RELEASE SITE \\
\hline 1989 & Tupman & 36 & Pozo, San Luis Obispo County \\
\hline 1990 & Concord & 53 & $\begin{array}{l}32 \text { - Parkfield, Monterey County } \\
21 \text { - Western Merced }\end{array}$ \\
\hline 1990 & Grizzly Island & 11 & Parkfield, Monterey County \\
\hline 1990 & Tupman & 2 & Fresno Zoo \\
\hline 1991 & Grizzly Island & 13 & San Ardo \\
\hline 1991 & Tupman & $\begin{array}{l}1 \\
2\end{array}$ & $\begin{array}{l}\text { La Panza } \\
\text { Lake Pillsbury }\end{array}$ \\
\hline
\end{tabular}

TOTAL

Relocation efforts, along with habitat improvements, have resulted in an increase of the tule elk population and occupied range in California from less than 700 when the Interagency Task Force was established in 1976, to 2,464-2,747 in 1991. However, this very successful relocation program has also created a significant conflict between tule elk and the State's agricultural and livestock industries. Currently, at least 12 of the 22 tule elk herds in California are causing damage to private property. Of the 22 free-roaming herds in the State, only the Bartlett Springs and Hunter Liggett herds are not creating depredation problems. Most of the damage is to fences, irrigation equipment, and agricultural crops.

Locating suitable release sites (as described in the Management Plan for the Conservation of Tule Elk, revised 1985) for surplus tule elk continues to be a significant problem. Due to the tendency of relocated tule elk to move great distances and cause extensive depredation problems, landowners are generally unwilling to accept tule elk on their lands unless CDFG can assure them that elk depredation and population levels can be controlled. CDFG must identify suitable release sites for surplus elk from the penned or confined herds at Concord, San Luis Refuge, Tupman Tule Elk Reserve, and Grizzly Island. It would be biologically and politically (as well as fiscally) unsound to relocate tule elk to an area where there is landowner opposition. Since there are more than 2,000 tule elk statewide, it is possible that depredation permits may have to be issued if relocated elk damage private property. 

Private lands currently support approximately 50 percent of the State's tule elk herds. Substantial additional privately owned lands suitable for tule elk relocations could become available if landowners were assured elk numbers would be managed at practical herd objective levels. Specifically, landowners have indicated they would like the ability to harvest tule elk that are damaging private property or elk that have exceeded a biologically based herd size objective. Until the private landowners are assured they can control elk numbers and elk damage, most are unwilling to allow CDFG to relocate tule elk onto or adjacent to their lands. Once sport hunting is available as an option to manage the species based on sound biological principles, numerous landowners have indicated a willingness to allow tule elk to be relocated to their lands or other property in the vicinity. When tule elk numbers and elk damage can be effectively controlled, landowners will cease viewing elk as a liability. 



\section{RECOMMENDED ACTIONS FOR CONTINUED MANAGEMENT AND EXPANSION OF TULE ELK RANGE}

Several areas with established tule elk herds will require management action to ensure their continued suitability for the maintenance of a healthy tule elk population. Areas with potential for transplants also require some degree of treatment to make them suitable for reintroduction. The goal of the California Statewide Management Plan for Tule Elk is to ensure the continued growth of healthy, free-roaming herds of sizes that are compatible with the suitable habitat in California. Following is a list of the highest priority actions, as identified by the Interagency Task Force, which are necessary to achieve that goal.

1. Develop and Implement Habitat Management Plans for Each Tule Elk Herd. Each land-managing agency administering existing tule elk habitat or potential transplant sites should develop and implement formal cooperative habitat management plans for their lands. Each plan should outline procedures for the continued existence of herds in a healthy balance with their habitat, other wildlife, and various forms of land use.

2. Continue to Identify Areas of Potential Tule Elk Habitat. An important part of achieving the management objective will be to continue the search for areas where tule elk can be relocated. Relocation will remain a viable management technique when tule elk in excess of the carrying capacity of an area are present. Essentially all lands in public ownership within historic tule elk range have been examined. Those areas with suitable habitat currently contain elk except for the areas rejected because of unresolvable land use conflicts. Therefore, most future releases will have to be on private lands.

3. Acquire or Develop Management Agreements for Private Lands to Preserve the Existing Cache Creek Tule Elk Herd. Habitat improvement on public lands used by the Cache Creek herd is not keeping pace with the decrease in habitat quality on private lands. Some 12,000 acres of crucial riparian and wet meadow habitats under private ownership are used by the Cache Creek herd as traditional rutting, feeding, calving, and bedding areas. These private lands must be managed in a manner which safeguards the Cache Creek herd. The Interagency Task Force on Tule Elk should complete an analysis to determine specific acquisition needs, costs and alternatives for acquisition, and responsibilities of participating agencies relative to the Cache Creek herd and other key areas involving private lands. The analysis should include alternative means of achieving objectives, including zoning and other similar land and resource management techniques, that would allow the habitat to remain in private ownership. It should be recognized, however, that ownership and/or management by a Federal or State agency or a private conservation organization may be necessary.

4. Provide the Funding Required for the Preparation. Implementation, and Update of Habitat Management Plans by Federal Agencies Maintaining Tule Elk on Lands Under Their Jurisdictions. Preparation of habitat management plans requires the detailed study of tule elk movements and requirements in any given area. Herd boundaries, calving, holding, and other critical areas, as well as range production on a seasonal basis, are but some of the factors 

that must be evaluated prior to development of a habitat management plan. Funding for such aspects of plan preparation is essential. Adequate funding also is needed for implementation and subsequent monitoring. Land acquisition, brush conversion, construction of fences and watering facilities, and other actions necessary for implementation of habitat management objectives can be expensive processes. Funds for maintenance of improvements also will be needed.

Once a plan is implemented, monitoring is necessary to assure that objectives are being met. Monitoring may include collection of data on tule elk demography, and periodic checks on habitat condition. This will provide the basis for updating plans; updates will be necessary when conditions change or when better data become available for assessing carrying capacity. 



\section{SUMMARY}

The current status of tule elk and their habitats is summarized in Table 3. Tule elk currently occupy approximately $1,500,000$ acres, of which 50 percent is administered by governmental agencies above the local level.

A total of 9,361 acres ( 0.7 percent) utilized by tule elk is in excellent condition. The majority of the habitat (1,407,000 acres, or 99 percent) is in good to fair condition; of this, there is a shift in some areas to the lower end of this condition class. Six hundred eighty five acres (less than 0.1 percent) are in fair to poor condition. The shift in some areas to fair or fair to poor condition is the result of five consecutive years of below normal precipitation.

The adverse effect of current or proposed land-use practices is summarized in Table 4 .

The land-managing agencies under the Secretary of the Interior, Secretary of Agriculture, and the Secretary of Defense are cooperating in making lands under their respective jurisdictions available for tule elk. In some cases, improving these lands to a condition suitable for tule elk requires the expenditure of funds for fences, watering facilities, or other developments. The military has been especially cooperative in making their lands available, so long as diverting military funds to accommodate the elk is not required.

The legislated population goal of 2,000 tule elk has been met and exceeded. The CDFG's most recent comprehensive estimate of the total statewide population of tule elk is between 2,464 and 2,747 animals.

The herd size objective which will maintain tule elk in a healthy condition has been prescribed or estimated for all sites currently utilized by the elk. At least nine of the herds (Owens Valley, Cache Creek, Grizzly Island, Potter Valley, Point Reyes, Camp Roberts, Laytonville, Pozo, and Fremont Peak) are currently above their herd size objective.

The location and evaluation of suitable areas for the reintroduction of tule elk is a major challenge facing resource managers. This is becoming an increasingly difficult task as fewer and fewer areas are available which do not pose potentially significant conflicts with other land uses. 



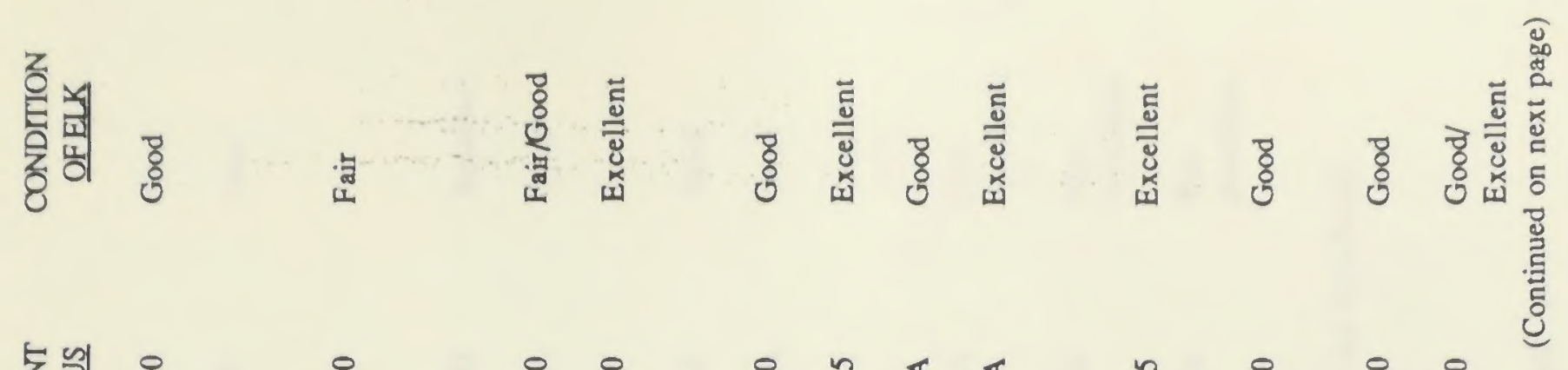

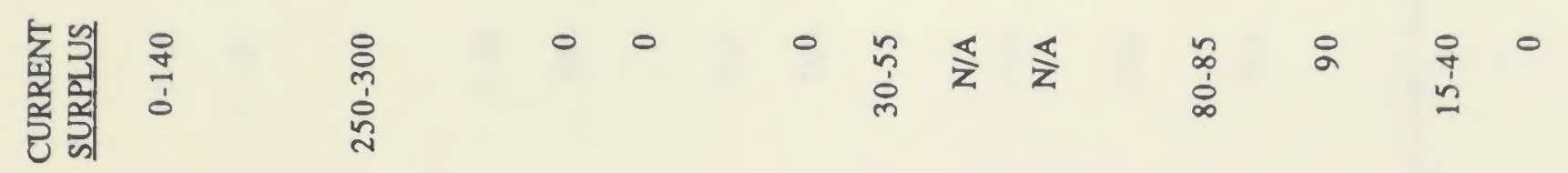

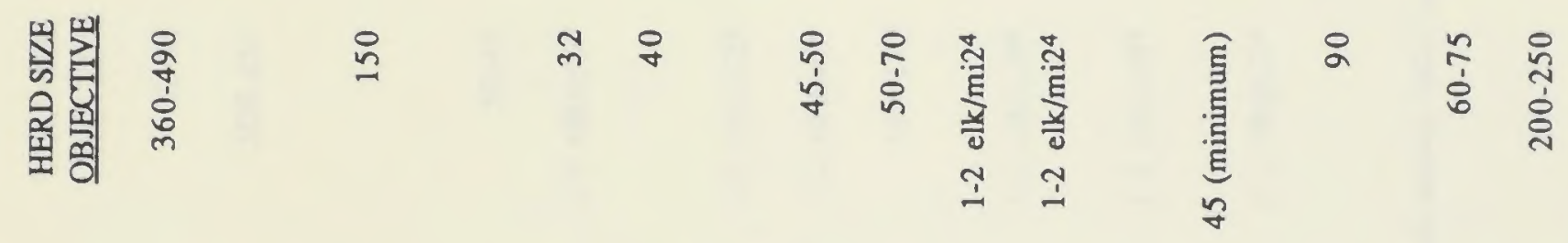

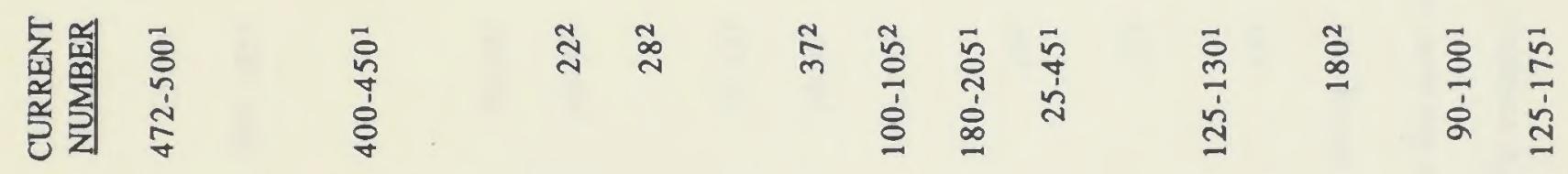

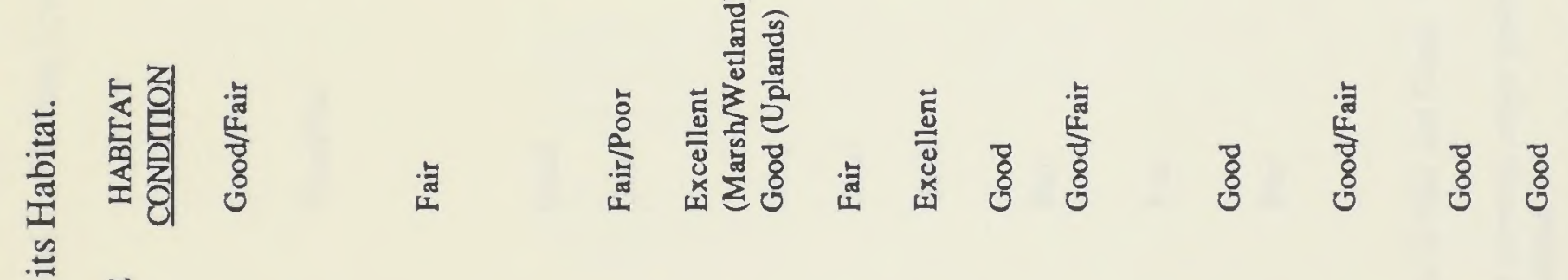

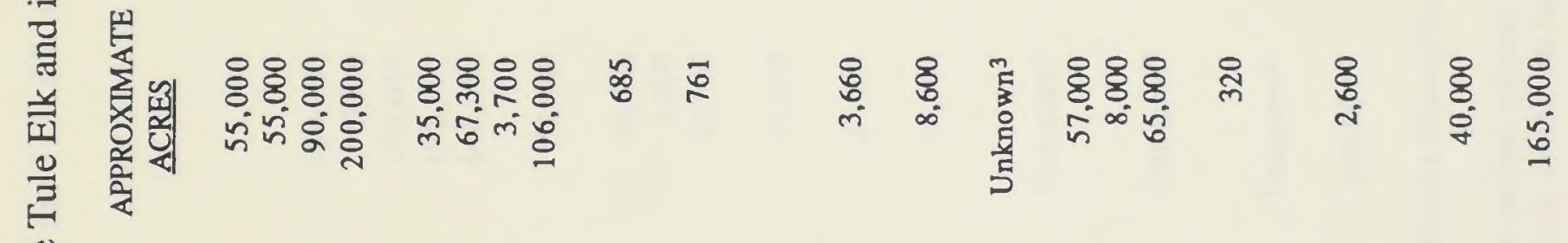

总

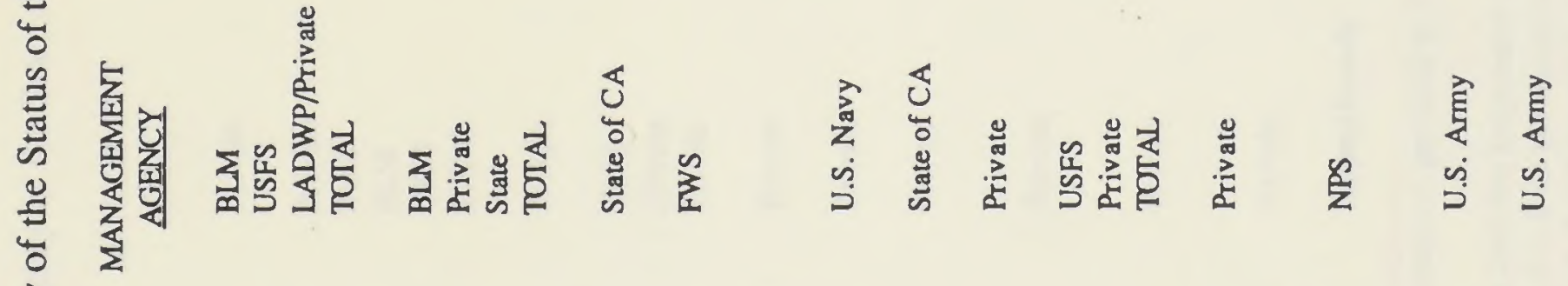

言

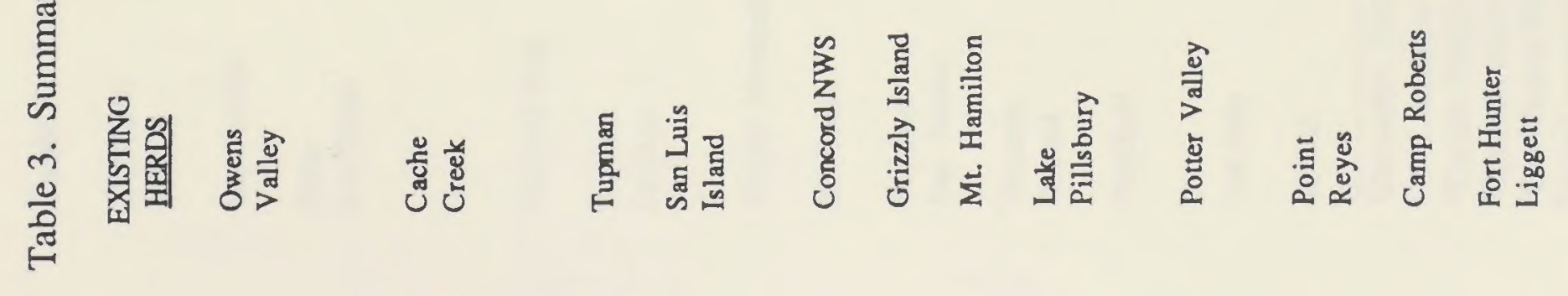





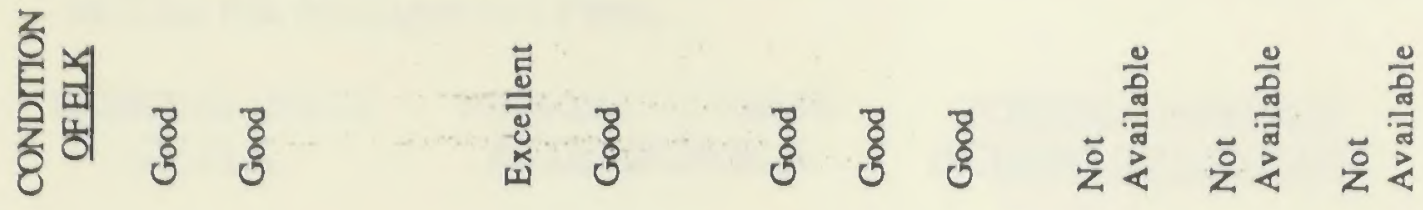

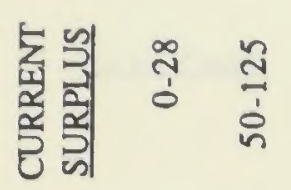

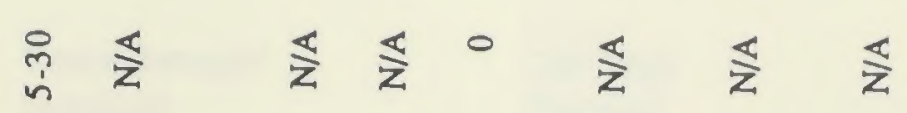

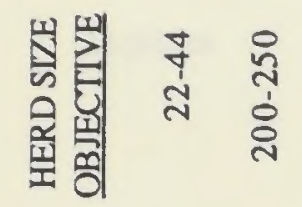

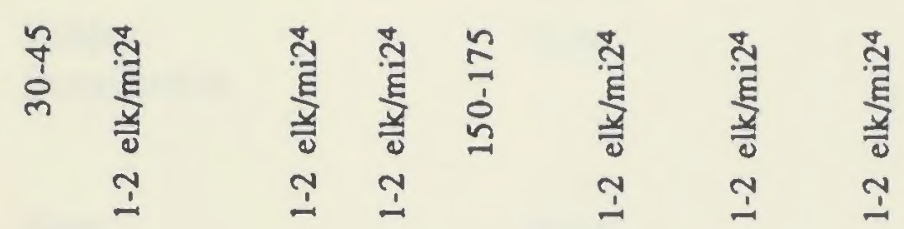

量

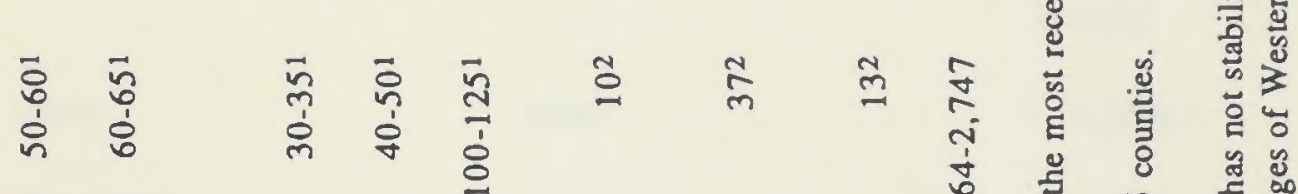

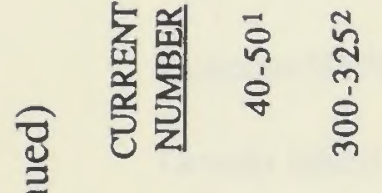

离

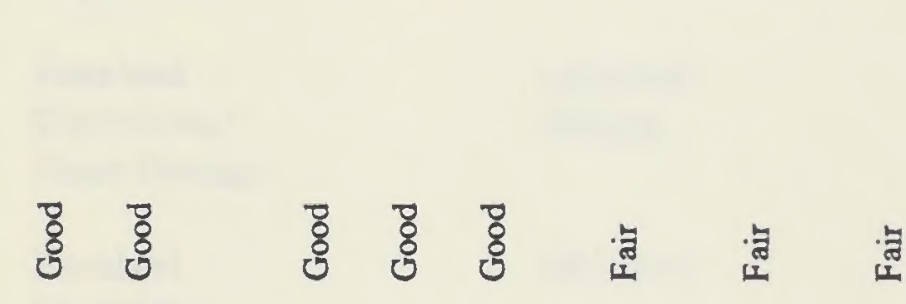

若 总

苍

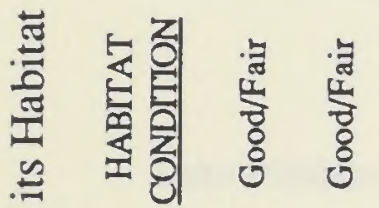

量

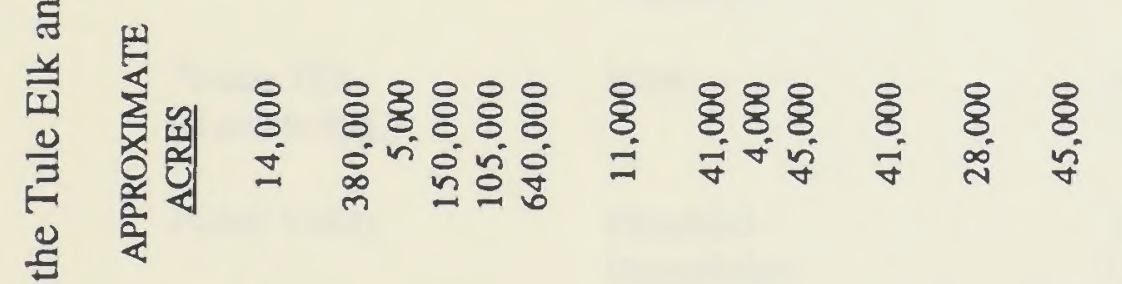

일

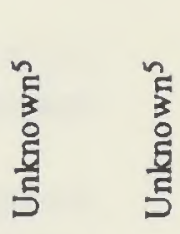

衰

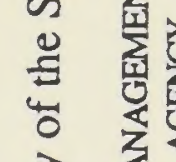

离

窗包

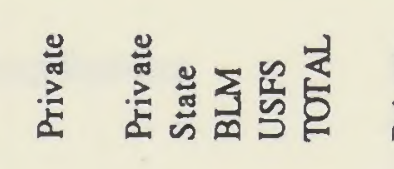

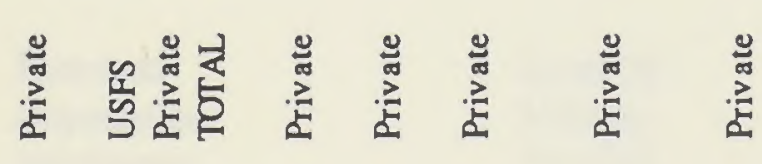

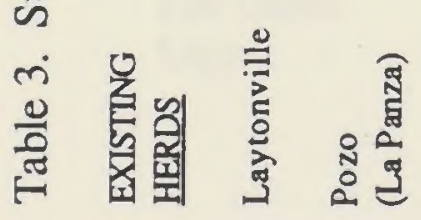

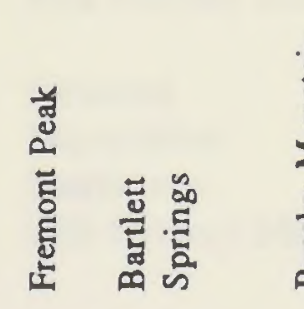

高

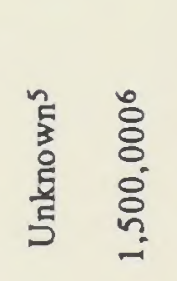

$\frac{n}{2}$

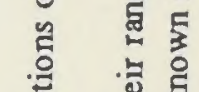

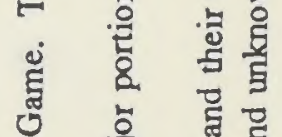

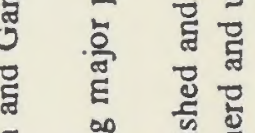

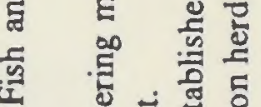

○ ठัँ

을 空

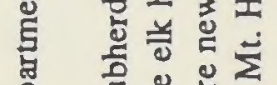

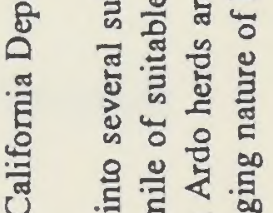

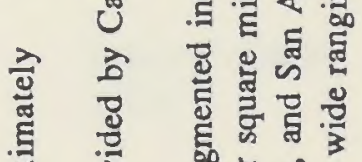

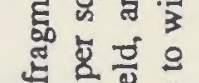

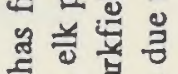

돈

च

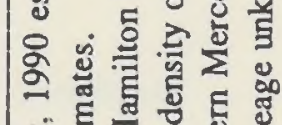

हี 

Table 4. Summary of Adverse Effects of Land-use Practices on the Tule Elk and the Status of Tule Elk Management Plans.

\begin{tabular}{|c|c|c|c|}
\hline EXISTING HERDS & POSSIBLE ADVERSE & POSSIBLE ADVERSE & $\begin{array}{c}\text { STATUS OF } \\
\text { MANAGEMENT PLAN }\end{array}$ \\
\hline & & 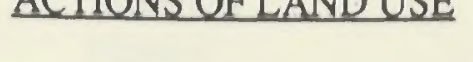 & \\
\hline Owens Valley & $\begin{array}{l}\text { Farmland } \\
\text { Depredation }\end{array}$ & ORV Use & $\begin{array}{l}\text { Completed/ } \\
\text { Revised }\end{array}$ \\
\hline Cache Creek & $\begin{array}{l}\text { Fence Damage/ } \\
\text { Farmland } \\
\text { Depredation }\end{array}$ & $\begin{array}{l}\text { Oak Tree } \\
\text { Harvest/ } \\
\text { Livestock } \\
\text { Grazing }\end{array}$ & $\begin{array}{l}\text { Completed/ } \\
\text { Revised }\end{array}$ \\
\hline Tupman & $\begin{array}{l}\text { Habitat } \\
\text { Deterioration }\end{array}$ & None & $\begin{array}{l}\text { Current Management } \\
\text { Plan Being } \\
\text { Developed }\end{array}$ \\
\hline $\begin{array}{l}\text { San Luis } \\
\text { Island }\end{array}$ & None & None & $\begin{array}{l}\text { Completed/ } \\
\text { Revised }\end{array}$ \\
\hline Concord NWS & None & None & Completed \\
\hline Grizzly Island & $\begin{array}{l}\text { Farmland } \\
\text { Depredation }\end{array}$ & None & Completed \\
\hline Mount Hamilton & $\begin{array}{l}\text { Farmland } \\
\text { Depredation/ } \\
\text { Fence Damage }\end{array}$ & $\begin{array}{l}\text { Livestock } \\
\text { Grazing }\end{array}$ & N/A \\
\hline Lake Pillsbury & $\begin{array}{l}\text { Farmland } \\
\text { Depredation }\end{array}$ & ORV Use & $\begin{array}{l}\text { N/A/ } \\
\text { Planned }\end{array}$ \\
\hline $\begin{array}{l}\text { Potato Hill } \\
\text { (Bartlett Spg.) }\end{array}$ & None & $\begin{array}{l}\text { ORV Use/ } \\
\text { Livestock }\end{array}$ & $M / A$ \\
\hline Potter Valley & $\begin{array}{l}\text { Farmland } \\
\text { Depredation }\end{array}$ & $\begin{array}{l}\text { Livestock } \\
\text { Grazing }\end{array}$ & Completed \\
\hline Point Reyes & None & None & $\begin{array}{l}\text { Interim Plan in } \\
\text { Effect }\end{array}$ \\
\hline Camp Roberts & $\begin{array}{l}\text { Farmland } \\
\text { Depredation/ } \\
\text { Interference } \\
\text { with Military Mission }\end{array}$ & $\begin{array}{l}\text { Increased } \\
\text { Military } \\
\text { Training }\end{array}$ & Completed \\
\hline $\begin{array}{l}\text { Fort Hunter } \\
\text { Liggett }\end{array}$ & $\begin{array}{l}\text { Farmland } \\
\text { Depredation/ } \\
\text { Interference } \\
\text { with Military Mission }\end{array}$ & $\begin{array}{l}\text { Increased } \\
\text { Military } \\
\text { Training }\end{array}$ & Completed \\
\hline Laytonville & $\begin{array}{l}\text { Farmland } \\
\text { Depredation }\end{array}$ & $\begin{array}{l}\text { Livestock } \\
\text { Grazing }\end{array}$ & Completed \\
\hline
\end{tabular}





\begin{tabular}{|c|c|c|c|}
\hline Pozo (La Panza) & Fence Damage & $\begin{array}{l}\text { Livestock } \\
\text { Grazing }\end{array}$ & Completed \\
\hline Fremont Peak & $\begin{array}{l}\text { Farmland } \\
\text { Depredation/ } \\
\text { Fence Damage }\end{array}$ & $\begin{array}{l}\text { Livestock } \\
\text { Grazing }\end{array}$ & Completed \\
\hline $\begin{array}{l}\text { Brushy } \\
\text { Mountain }\end{array}$ & $\begin{array}{l}\text { Fence Damage/ } \\
\text { Farmland } \\
\text { Depredation }\end{array}$ & None & Completed \\
\hline Elk Creek & Fence Damage & None & Completed \\
\hline $\begin{array}{l}\text { Southern } \\
\text { San Benito }\end{array}$ & $\begin{array}{l}\text { Farmland } \\
\text { Depredation/ } \\
\text { Fence Damage }\end{array}$ & None & N/A \\
\hline $\begin{array}{l}\text { Westem } \\
\text { Merced }\end{array}$ & $\begin{array}{l}\text { Farmland } \\
\text { Depredation/ } \\
\text { Fence Damage }\end{array}$ & $\begin{array}{l}\text { Livestock } \\
\text { Grazing }\end{array}$ & N/A \\
\hline Parkfield & $\begin{array}{l}\text { Farmland } \\
\text { Depredation/ } \\
\text { Fence Damage }\end{array}$ & $\begin{array}{l}\text { Livestock } \\
\text { Grazing }\end{array}$ & N/A \\
\hline San Ardo & $\begin{array}{l}\text { Farmland } \\
\text { Depredation/ } \\
\text { Fence Damage }\end{array}$ & $\begin{array}{l}\text { Livestock } \\
\text { Grazing }\end{array}$ & N/A \\
\hline
\end{tabular}





\section{APPENDIX A}

\section{LEGISLATION}

State Fish and Game Code Sections Pertaining to Tule Elk

§332. Elk; commission authority; license fee, etc.

(a) The commission may determine and fix the area or areas, the seasons and hours, the bag and possession limit, and the number of elk that may be taken under rules and regulations the commission may prescribe from time to time. The commission may authorize the taking of tule elk if the average of the department's statewide tule elk population estimates exceeds 2,000 animals, or the Legislature determines, pursuant to the reports required by Section 3951, that suitable areas cannot be found in California to accommodate that population in a healthy condition.

(b) Only a resident of the State of California over the age of 16 years and possessing a valid hunting license may obtain a license for the taking of elk.

(c) The department may issue an elk license upon payment of a fee of one hundred sixty-five dollars (\$165), as adjusted under Section 713. The fee may include a nonrefundable application fee in an amount determined to be sufficient to pay the costs of administering the management of tule elk under Section 3951. The fees shall be deposited in the Fish and Game Preservation Fund and shall be expended, in addition to money budgeted for salaries of the department, for the expense of enforcing this section and the processing of the applications. (Amended by Stats 1977 ch 353; Stats 1985 ch 1463; Stats 1986 ch 1368; Stats 1987 ch 1229 §1, eff. 9/27/87.)

\section{§3951. Tule elk.}

The commission may authorize the taking of tule elk pursuant to Section 332. The department shall relocate tule elk in areas suitable to them in the State of California and shall cooperate to the maximum extent possible with federal and local agencies and private property owners in relocating tule elk in suitable areas under their jurisdiction or ownership. When economic or environmental damage occurs, emphasis shall be placed on managing each tule elk herd at a biologically sound level through the use of relocation, sporthunting, or other appropriate means as determined by the department after consulting with local landowners.

The number of tule elk in the Owens Valley shall not be permitted to increase beyond 490, or any greater number hereafter determined by the department to be the Owens Valley's holding capacity in accordance with game management principles. Within 180 days of the enactment of the bill which amended this section at the 1987 portion of the 1987-88 Regular Session of the Legislature, the department shall complete management plans for high priority areas including, but not limited to, Potter Valley and Mendocino County. The plans shall include, but not be limited to:

(1) Definition of the boundaries of the management area.

(2) Characteristics of the tule elk herds within the management area.

(3) The habitat conditions and trends within the management area.

(4) Major factors affecting the tule elk population within the management area, including, but not limited to, conflicts with other land uses.

(5) Management activities necessary to achieve the goals of the plan.

The Director of Fish and Game shall submit a report describing the status of tule elk, as herein set forth, to the commission and to the Governor for transmittal to the Legislature no later than the fifth legislative day of the 1974 Regular Session of the Legislature and every two years thereafter. The report shall also include, but not be limited to:

(1) The population status of tule elk in California.

(2) Age and sex information.

(3) Condition of their ranges.

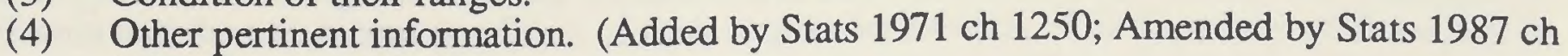
$1229 \S 2$, eff. 9/27/87.) 



\section{Public Law 94-389}

Providing for Federal participation in preserving the tule elk population in California.

Whereas, although tule elk once roamed the central valleys of California in vast numbers, the species became nearly extinct during the latter part of the last century as a result of its native habitat being developed for agricultural purposes and urban growth; and

Whereas, although around 1870 the tule elk population reached a low of approximately thirty animals, through the dedicated efforts of various citizen groups and individual cattlemen, the population has slowly recovered to a total of approximately six hundred animals, the majority of which may be found in free-roaming herds in the Owens Valley, at Cache Creek in Colusa County, California, a small number which are captive in the Tupman Refuge in Kern County, California; and

Whereas in 1971, the California Legislature, recognizing the threat to the tule elk as a species, amended section 332 and enacted section 3951 of the Fish and Game Code which provide for the encouragement of a statewide population of tule elk of not less than two thousand, if suitable areas can be found in California to accommodate such population in a healthy environment, and further fixed the population of the tule elk in the Owens Valley at four hundred and ninety animals, or such greater number as might thereafter be determined by the California Department of Fish and Game, in accordance with game management principles, to be the Owens Valley holding capacity; and

Whereas the tule elk is considered by the Department of the Interior to be a rare, though not endangered, species by reason of the steps taken by the State of California; and

Whereas the protection and maintenance of California's tule elk in a free and wild state is of educational, scientific, and aesthetic value o the people of the United States; and

Whereas there are Federal lands in the State of California (including but not limited to, the San Luis National Wildlife Refuge, the Point Reyes National Seashore, various national forests and national parks, and Bureau of Land Management lands located in central California, as well as lands under the jurisdiction of the Secretary of Defense such as Camp Pendleton, Camp Roberts, and Camp Hunter Liggett) which, together with adjacent lands in public and private ownership, offer a potential for increasing the tule elk population in California to the two thousand level envisioned by the California legislature: Now therefore, be it

Resolved by the Senate and House of Representatives of the United States of America in Congress assembled, that it is the sense of Congress that the restoration and conservation of a tule elk population in Califomia of at least two thousand except that the number of tule elk in the Owens River Watershed area shall at no time exceed four hundred and ninety or such greater number which is determined by the State of California to be the maximum holding capacity of such area, is an appropriate national goal.

SEC. 2. The Secretary of the Interior, the Secretary of Agriculture, and the Secretary of Defense shall cooperate with the State of California in making the lands under their respective jurisdictions reasonably available for the preservation and grazing of tule elk in such manner and to such extent as may be consistent with Federal law.

SEC. 3. The Secretary of the Interior shall submit, on or before the first of March of every year, a report to the Congress as to the estimated size and condition of the various tule elk herds in California and the nature and condition of their respective habitats. The Secretary shall include in such report his determination as to whether or not the preservation of the tule elk herd at its 

then-existing level is, or may be, endangered or threatened by actual or proposed changes in land use or land management practices on lands owned by any Federal, State, or local agency, together with his recommendations as to what Federal actions, if any, should be taken in order to preserve the tule elk herds at the then existing level or such other level as may be determined from time to time by the State of California.

SEC. 4. The Secretary of the Interior, in coordination with all Federal, State, and other officers having jurisdiction over lands on which tule elk herds are located or lands which would provide suitable tule elk habitat, shall develop a plan for tule elk restoration and conservation, including habitat management which shall be integrated with the comparable plans of State and local authorities in California. The Secretary's annual report to Congress shall describe the development and implementation of such plan. 


